\title{
Proces wprowadzania
}

\section{dwujęzycznych nazw miejscowości na Opolszczyźnie i ich społeczny odbiór}

\section{MARIA WAGIŃSKA-MARZEC}

Instytut Zachodni im. Zygmunta Wojciechowskiego w Poznaniu

(iD) https://orcid.org/0000-0003-4508-0385

\section{ROCZNIK}

\section{ZIEM}

\section{ZACHODNICH}

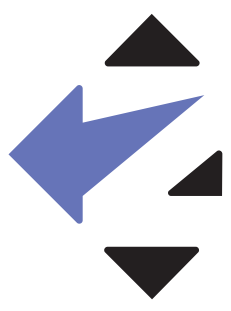




\section{Wprowadzenie}

W okresie powojennym władze komunistyczne forsowały tezę, że Polska jest państwem jednolitym narodowościowo, a ogólna liczba osób należących do mniejszości narodowych stanowi jedynie nieco ponad 1\% ogółu ludności, co „w sposób rażący” rozmijało się z rzeczywistością ${ }^{1}$. Podobnie uważa historyk i politolog Michał Lis, dowodząc, iż do upadku systemu realnego socjalizmu władze polskie zaprzeczały istnieniu mniejszości niemieckiej w Polsce ${ }^{2}$. „To władze polityczne określały, która grupa może być uznana za mniejszość oraz w jakim zakresie może ona działać" - stwierdza socjolog Sławomir Łodziński, dodając, że w ówczesnym systemie prawnym nie występował w ogóle termin „mniejszość narodowa”; był on zastępowany

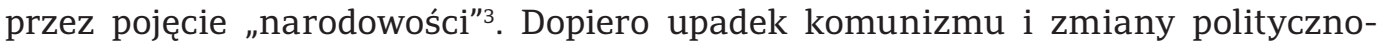
-prawne po 1989 r. wpłynęły na zmianę stosunku państwa do mniejszości narodowych. Wyrazem tego było wypracowanie nowych założeń polityki narodowościowej i stworzenie sprzyjających warunków rozwoju dla mniejszości narodowych i etnicznych w Polsce.

Przemiany społeczno-demokratyczne na przełomie lat 80. i 90. XX w. przyczyniły się również do zmiany postaw społecznych wobec niemieckiej spuścizny kulturowej na Ziemiach Zachodnich i Północnych ${ }^{4}$. Wpływ na to miało kilka czynników: likwidacja ograniczeń cenzuralnych (co wiązało się ze swobodą głoszenia poglądów), demokratyzacja życia politycznego (czego przejawem był rozwój samorządności stymulującej tożsamość lokalną) i wreszcie generalna poprawa stosunków polsko-niemieckich, a co za tym idzie - odpolitycznienie problemu dziedzictwa kulturowego ${ }^{5}$. Jak zauważył znawca problematyki, historyk Zbigniew Mazur, w społecznościach zamieszkałych przez mniejszości narodowe i etniczne ujawniła się wówczas „wyraźna i nagląca potrzeba wypracowania nowego, własnego modelu tożsamości kulturowej oraz ściśle z tym związana konieczność ponownego samookreślenia

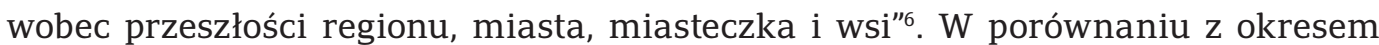

1 Zob.: Mniejszość niemiecka na terenie Rzeczypospolitej Polskiej, http://www.agdm.pl/index.php?option=com_content\&view=article\&id=87\&Itemid=10\&lang=pl (dostęp: 15 X 2016 r.).

2 M. Lis, Mniejszość niemiecka na Ślq̨sku Opolskim 1989-2014. Z bagażem przeszłości w realiach współczesności, Opole 2015, s. 53.

3 S. Łodziński, Przed ustawq o mniejszościach. Charakter instytucjonalizacji praw osób należqcych do mniejszości narodowych po 1989 roku a ustawa o mniejszościach z 2005 roku, [w:] Między lękiem a nadziejq. Dziesięć lat funkcjonowania ustawy o mniejszościach narodowych i etnicznych oraz o języku regionalnym (2005-2015), red. A. Adamczyk, A. Sakson, C. Trosiak, Poznań 2015, s. 28.

4 Świadczą o tym wypowiedzi uczestników spotkań środowiskowych organizowanych w ramach badań nad niemieckim dziedzictwem kulturowym na Ziemiach Zachodnich i Północnych. O postawach wobec niemieckiej przeszłości tych ziem i niemieckiej spuścizny kulturowej oraz o stosunku obecnych mieszkańców do "Małej Ojczyzny” zob. szerzej: Z. Mazur, Rozmowy o niemieckim dziedzictwie kulturowym. Raport ze spotkań środowiskowych na Ziemiach Zachodnich i Pótnocnych (1995-1996), Poznań 1997 (mps w zbiorach Instytutu Zachodniego).

5 Z. Mazur, O adaptacji niemieckiego dziedzictwa kulturowego na Ziemiach Zachodnich i Północnych, Poznań 2001, s. 12 
minionym pojawiły się na tych terenach całkiem nowe zjawiska, uprzednio prawie zupełnie nieobecne $\mathrm{w}$ życiu publicznym bądź też ledwo zauważalne. Zbigniew Mazur uważał, iż odkrywanie „pełnej związków i zrostów” przeszłości sprawiało, że niemiecki wątek historii stawał się „integralną częścią historii danej miejscowości, miasta i regionu”, wchodził w skład „podłoża historycznego”, na którym ludność polska budowała w nowych uwarunkowaniach swoje życie. Tradycja osadzona silnie w „upodmiotowionej historii regionu” mogła dzięki temu odegrać, jego zdaniem, istotną rolę w procesie kształtowania się tożsamości społeczności lokalnych i regionalnych, choć należy pamiętać, że równie ważny wpływ na ów proces miała tradycja ludności napływowej, przybyłej na te tereny, oraz jej pamięć o własnej dawnej małej ojczyźnie i trudnych początkach w nowym miejscu zamieszkania7. Poniemieckie zabytki zaczynały odtąd funkcjonować na zupełnie innych zasadach; ważny stał się przekaz o historii miejsca.

Dążenie do kształtowania własnej tożsamości regionalnej po 1989 r. spowodowało uruchomienie wielu oddolnych inicjatyw związanych $\mathrm{z}$ artykułowaniem swej odrębności w rejonach zamieszkiwanych przez mniejszości narodowe. Dało się to zaobserwować zwłaszcza na terenie Śląska Opolskiego, gdzie występuje największe skupisko ludności pochodzenia niemieckiego (ok. 90\%); część ludności identyfikującej się z niemieckością zamieszkuje też obszary Warmii i Mazur; mniejsze grupy są rozproszone na terenie całej Polski ${ }^{8}$. Mniejszość niemiecka stanowi de facto najliczniejszą grupę wśród mniejszości narodowych.

Szansę na rozwijanie aktywności społeczno-kulturalnej i jawne manifestowanie swej niemieckości stworzyła instytucjonalizacja ruchu mniejszości niemieckiej oraz powstawanie towarzystw społeczno-kulturalnych zrzeszających przedstawicieli mniejszości niemieckiej ${ }^{9}$. Jednym z pierwszych było utworzone w $1990 \mathrm{r}$. z inicjatywy Jana Króla (Johann Kroll) Towarzystwo Społeczno-Kulturalne Mniejszości Niemieckiej na Śląsku Opolskim (TSKN; Sozial-Kulturelle Gesellschaft der Deutschen Minderheit im Oppelner Schlesien) z siedzibą w Gogolinie, zajmujące się promowaniem kultury niemieckiej na obszarze Śląska Opolskiego ${ }^{10}$. Wkrótce zaczęły powstawać jego oddziały terenowe, tzw. Niemieckie Koła Przyjaźni (Deutsche Freundschaftskreise; DFK) ${ }^{11}$. Fakt ten wpłynął w dużej mierze na możliwość wzmocnienia

8 Zob.: m.in.: A. Sakson, Rola mniejszości niemieckiej w stosunkach polsko-niemieckich na przykładzie Warmii i Mazur, „Zeszyty Instytutu Zachodniego”, nr 11 (1998), s. 1.

9 Na przełomie 1989/1990 r. na ok. 37,8 mln mieszkańców w Polsce w towarzystwach społeczno-kulturalnych mniejszości narodowych zrzeszonych było od ok. 850 tys. do 1,1 mln osób, w tym 300-400 tys. ludności należącej do mniejszości niemieckiej. Szerzej na temat stowarzyszeń mniejszości niemieckiej w różnych regionach Polski oraz udziału przedstawicieli mniejszości we władzach samorządowych, zob. Mniejszość niemiecka na terenie Rzeczypospolitej..

10 Szerzej na temat początków organizowania się mniejszości niemieckiej na Śląsku Opolskim zob M. Lis, op. cit., s. 64-78, 85-91.

11 Obecnie na terenie województwa opolskiego istnieje ok. 330 kół DFK. Szerzej o działalności towarzystw społeczno-kulturalnych mniejszości niemieckiej w Polsce zob.: B. Nitschke, Przeobrażenia i specyfika działalności organizacji mniejszości niemieckiej, [w:] Między lękiem a nadziejq..., s. 157-168. 
identyfikacji Ślązaków z niemieckością i odtworzenia ich niemieckiej tożsamości, jak zauważyła Danuta Berlińska, socjolog z Uniwersytetu Opolskiego, pełniąca wówczas funkcję pełnomocnika ds. mniejszości przy wojewodzie opolskim ${ }^{12}$.

Skomplikowane losy i sytuację ludnościową na Śląsku Opolskim w wyniku ustaleń politycznych po II wojnie światowej oraz proces tworzenia się struktur organizacyjnych mniejszości niemieckiej po 1989 r. przedstawił szczegółowo Michał Lis $\mathrm{w}$ jednej ze swych prac poświęconych problematyce tego regionu, omawiając to zagadnienie na tle ówczesnych uwarunkowań społeczno-politycznych. Nakreślił przy tym okoliczności i klimat, jakie towarzyszyły legalizacji działalności niemieckich stowarzyszeń społeczno-kulturalnych na tym terenie. Autor zaprezentował też późniejsze formy zaangażowania mniejszości w życie społeczno-polityczne regionu jako jego „współgospodarza” ${ }^{13}$. Z kolei zagadnienie reaktywacji działalności kulturalnej towarzystw niemieckich na terenie Dolnego Śląska po 1989 r. podjęła Irena Kurasz, ilustrując to zjawisko na przykładzie Wrocławia, Wałbrzycha, Legnicy i Kamiennej Góry ${ }^{14}$. Sprawom mniejszości narodowych i etnicznych, ochronie ich praw, przejawom poszukiwania tożsamości, etc. poświęcono wiele uwagi również w innych opracowaniach naukowych ${ }^{15}$.

Jedną z charakterystycznych oznak zainteresowania mieszkańców przeszłością swej „małej ojczyzny” było m.in. ożywienie zainteresowania niemieckim nazewnictwem miejscowości. Spory o nazwy miejscowości, jako trwałe wyznaczniki odrębności regionalnej i lokalnej, stały się jednym z ważniejszych przejawów walki o własną tożsamość, a jednocześnie powodem wielu konfliktów i napięć społecznych. Potwierdza to spostrzeżenie Lecha M. Nijakowskiego w pracy poświęconej konfliktom narodowym i etnicznym w wymiarze symbolicznym, który stwierdził, że

12 Szerzej zob.: D. Berlińska, Niemieckie dziedzictwo kulturowe jako element rekonstrukcji tożsamości mniejszości niemieckiej na Ślasku Opolskim, [w:] Wspólne dziedzictwo? Ze studiów nad stosunkiem do spuścizny kulturowej na Ziemiach Zachodnich i Północnych, red. Z. Mazur, Poznań 2000, s. 553-584, zwłaszcza s. 561 .

13 M. Lis, op. cit., s. 7.

14 Zob.: I. Kurasz, Mniejszość niemiecka na Dolnym Ślq̨sku. Studium socjologiczne, Kraków 2015, s. 138-144

15 Zob. m.in.: Mniejszości narodowe w Polsce. Praktyka po 1989 roku, red. B. Berdychowska, Warszawa 1998; Z. Kurcz, Mniejszość niemiecka w Polsce, Wrocław 1995; D. Berlińska, Mniejszość niemiecka na Ślq̨sku Opolskim w poszukiwaniu tożsamości, Opole 1999; eadem, T. Sołdra-Gwiżdż, Ludność rodzima i mniejszość niemiecka w Polsce, [w:] Polskie badania nad mniejszościami kulturowymi. Wybrane zagadnienia, „Pogranicze. Studia Społeczne”, t. VI (1997), s. 73-103; A. Trzcielińska-Polus, Mniejszość niemiecka na Ślqsku Opolskim - atut czy wyzwanie dla regionu?, [w:] Między lękiem a nadziejq..., s. 145-155; K. Kersten, Przemiany struktury narodowościowej Polski po II wojnie światowej. Geneza i wyniki, „Kwartalnik Historyczny”, R. 76 (1969), nr 2, s. 337-366; S. Łodziński, „Niebanalna” dwujęzyczność. Polska tożsamość narodowa a granice integracji mniejszości narodowych, [w:] Naród - tożsamość - kultura. Między koniecznościq a wyborem, red. J.W. Burszta, K. Jaskułowski, J. Nowak, Warszawa 2005, s. 177-197; P. Madajczyk, Niemcy polscy 1944-1989, Warszawa 2001; Polityka państwa polskiego wobec mniejszości narodowych i etnicznych, red. L.M. Nijakowski, Warszawa 2005. Zob. też: Tożsamość narodowa Polaków oraz postrzeganie mniejszości narodowych i etnicznych w Polsce. Komunikat z badań, oprac. J. Lewandowska, Warszawa 2005, s. 1-10. Por.: Tożsamość narodowa i postrzeganie praw mniejszości narodowych i etnicznych, oprac. M. Omyła-Rudzka, „Komunikat z badań”, nr 106 (2015), s. 1-13. 
Grupy etniczne i narody nieraz toczą spory o znaczące miejsca i symbole. Przedmiotem niejednokrotnie emocjonalnych konfliktów są pomniki, mauzolea, groby i cmentarze, zabytki, miejsca święte, rocznice wydarzeń historycznych, pieśni i znaki graficzne, obecność w przestrzeni publicznej nazw i języka danej grupy itd. ${ }^{16}$

Dążenia do zmian w "krajobrazie semantycznym” traktuje on jako chęć budowy identyfikacji etnicznej i podtrzymania etnicznej wspólnoty znaczeń w ramach mniejszości ${ }^{17}$.

Jednym ze stałych punktów katalogu dezyderatów wysuwanych przez liderów mniejszości niemieckiej pod adresem rządu polskiego był właśnie postulat wprowadzenia „dwujęzycznych nazw miejscowości i innych terminów geograficznych oraz wprowadzenia języka niemieckiego, jako drugiego urzędowego" w skupiskach ludności pochodzenia niemieckiego, zamieszczony w Memoriale Rady Naczelnej Stowarzyszeń Niemieckich $w$ Rzeczypospolitej Polskiej (11 października 1990 r.) ${ }^{18}$. Sprawa podwójnych nazw na Opolszczyźnie stała się odtąd niejako sztandarowym hasłem mniejszości niemieckiej, jednej z najprężniej działających, najlepiej zorganizowanych i najgłośniej domagającej się swych praw grupy mniejszości narodowych; została też natychmiast podchwycona przez środowiska ziomkowskie i spotkała się z szerokim oddźwiękiem w prasie niemieckiej, która wyraźnie wspierała działania mniejszości niemieckiej w tym kierunku ${ }^{19}$.

Dodatkowe nazwy miejscowości były traktowane przez mniejszość niemiecką jako „ważne dobro symboliczne, jako część ich genealogii, historii rodzin oraz indywidualnych biografii" - jak wynika z badań przeprowadzonych przez Sławomira Łodzińskiego na terenie województwa opolskiego ${ }^{20}$. Zwraca on uwagę, iż z perspektywy różnych doświadczeń pokoleniowych mniejszości mają one różne znaczenie: dla ludzi starszych oznaczają „powrót do tego, gdzie się urodzili”; dla ludzi średniego pokolenia to „podkreślenie pewnej podmiotowości”, zaznaczenie swojej obecności; a dla ludzi młodych to swoisty „rodzaj refleksyjności” ${ }^{21}$. Dodatkowe nazwy są zatem traktowane, według Łodzińskiego, jako część własnej tożsamości narodowej oraz regionalnej (śląskiej); są bowiem wyrazem poczucia przynależności lokalnej, wyrażającej się $\mathrm{w}$ „potrzebie zaznaczenia własnego miejsca poprzez odniesienie się

16 L.M. Nijakowski, Domeny symboliczne. Konflikty narodowe $i$ etniczne w wymiarze symbolicznym, Warszawa 2006, s. 11.

17 Ibidem, s. 171-181.

18 Zob.: Memoriał Rady Naczelnej Stowarzyszeń Niemieckich w Rzeczypospolitej Polskiej, [w:] M. Lis, Ludność rodzima na Ślq̨sku Opolskim po II wojnie światowej (1945-1993), Opole 1993, s. 196-199.

19 K. Tokarz, Mniejszość niemiecka w Polsce w prasie RFN lat 1989-1997, [w:] Węzłowe problemy Niemiec XX-XXI wieku, red. K. Fiedor, M.S. Wolański, Wrocław 2002, s. 161.

20 S. Łodziński, Refleksyjne dziedzictwo? Dodatkowe nazwy niemieckie jako symbol tradycji terytorialnej ojczyzny lokalnej (przykład województwa opolskiego), [w:] Dziedzictwo kulturowe Ślqska: miejsca, architektura, Ludzie, zwyczaje, tradycje: XVIII Seminarium Ślqqskie, red. G. Schiller, Kamień Śląski 2013, s. 17.

21 Ibidem 
do przeszłości i podtrzymanie jej ciągłości". Łodziński wskazuje na znaczenie tego faktu w sensie kulturowo-historycznym. Nazwy dwujęzyczne mogą być bowiem rozpatrywane jako „jeden z instrumentów przywracających i terytorializujących swoją ojczyznę, własny stary teren zamieszkania"22. Jego zdaniem z perspektywy społecznej dodatkowe (mniejszościowe) nazwy miejscowości stanowią „wizualizację granic etnicznych w regionie”, pełnią funkcję „etnicznych markerów”, wyznaczając obszar przynależności do społeczności etnicznych oraz terenu, na którym zamieszkują. Obecność dodatkowych nazw miejscowości stwarza jednocześnie możliwość rozwoju poczucia wspólnoty regionalnej poprzez wyeksponowanie tradycji historycznych danego terenu i zwrócenie uwagi na jego dawnych i obecnych gospodarzy. W tym sensie nazwy te stanowią „narzędzie konstruowania i utrwalania identyczności grupy jako wspólnoty kulturowej (etnicznej)"23.

Trwające od początku lat 90. XX w. konflikty wokół kwestii wprowadzenia dwujęzycznych nazw miejscowości były na tyle gwałtowne, że stały się przedmiotem zainteresowania badaczy i tematem wielu opracowań naukowych ${ }^{24}$, wystąpień na konferencjach poświęconych zagadnieniom Ziem Zachodnich i Północnych ${ }^{25}$, a także licznych artykułów i komentarzy prasowych (w prasie lokalnej i ogólnopolskiej ${ }^{26}$, jak również dyskusji publicznych. O różnych inicjatywach i działaniach związanych z wprowadzeniem podwójnych nazw miejscowości na Opolszczyźnie obszernie i emocjonalnie donosiły zwłaszcza wydawnictwa mniejszościowe ${ }^{27}$ oraz prasa ziomkowska.

Intensywne i długotrwałe zabiegi liderów mniejszości niemieckiej o przyspieszenie prac legislacyjnych dotyczących wprowadzenia tablic z podwójnymi nazwami miejscowości na ich terenie zostały ostatecznie uwieńczone sukcesem w postaci

24 Zob. m.in.: M. Choroś, O dqżeniu do wprowadzenia dwujęzycznych nazw miejscowości na Ślasku Opolskim, „Śląsk Opolski”, nr 2 (2001), s. 90-95; eadem, Ł. Jarczak, Wprowadzanie dwujęzycznych nazw miejscowości na Ślq̨sku Opolskim po 1989 roku, „Studia Śląskie”, t. 69 (2010), s. 217-237; M. Choroś, Dwujęzyczne tablice z nazwami miejscowości na Opolszczyźnie: przejaw demokracji czy źródło nowych konfliktów?, „Przegląd Zachodni”, nr 1 (2012), s. 127-142; M. Wagińska-Marzec, Spory o nazwy miejscowości na Opolszczyźnie jako syndrom walki o tradycję, „Zeszyty Instytutu Zachodniego”, nr 27 (2002), s. 1-46; eadem, Postawy mieszkańców Opolszczyzny wobec podwójnych nazw miejscowości, „Zeszyty Instytutu Zachodniego", nr 31 (2003), s. 1-68; eadem, Kwestia podwójnego nazewnictwa miejscowości na Opolszczyźnie w stosunkach polsko-niemieckich, „Opinie i Ekspertyzy”, nr 5 (2004), s. 1-44; S. Łodziński, Polityka etniczna - od standardu międzynarodowego do prawa krajowego i poziomu lokalnego (gminy). Przykład instytucjonalizacji praw językowych osób należacych do mniejszości narodowych w Polsce, [w:] Polityka etniczna. Teorie - koncepcje - wyzwania, red. T. Browarek, H. Chałupczak, E. Pogorzała, R. Zenderowski, cz. III: Polityka etniczna państw i regionów, Lublin 2015, s. 397-401.

25 M.in. na konferencji w Słupsku pt. Ziemie Odzyskane / Ziemie Zachodnie i Północne 1945-2005 - 60 lat $w$ granicach państwa polskiego, 9-10 VI $2005 \mathrm{r}$

26 Obszerne komentarze na ten temat ukazywały się przede wszystkim na łamach: „Nowej Trybuny Opolskiej”, „Trybuny Śląskiej”, „Gazety w Opolu”, „Życia”, „Dziennika Zachodniego”, „Rzeczypospolitej”, „Przeglądu Tygodniowego”, „Polityki”, „Gazety Wyborczej”, „Naszego Dziennika”, etc.

27 Donosiły o tym szeroko zwłaszcza: „Schlesisches Wochenblatt” i „Oberschlesische Zeitung. Gazeta Górnośląska". 
uregulowań, jakie wniosła Ustawa o mniejszościach narodowych i etnicznych oraz o języku regionalnym, uchwalona 6 stycznia $2005 \mathrm{r}^{28}$

Celem niniejszego opracowania będzie prześledzenie procesu wdrażania podwójnego nazewnictwa miejscowości na obszarze Śląska Opolskiego (oraz w niektórych gminach województwa śląskiego), jako największego skupiska mniejszości niemieckiej, dzięki możliwościom stworzonym przez powyższą ustawę. Moim zamiarem jest przedstawienie praktyki społecznej związanej z wprowadzaniem dwujęzycznych nazw miejscowości na tym terenie i odzwierciedlenie trudności, jakie się z tym wiązały, a także ukazanie różnych postaw wobec problemu dwujęzycznego nazewnictwa miejscowości (przedstawicieli miejscowych władz, działaczy mniejszości niemieckiej oraz lokalnej społeczności); chodzi o uwypuklenie emocji społecznych, jakie problem ten wzbudzał w środowisku. Przedmiotem zainteresowania będzie przebieg realizacji zapisów ustawy w odniesieniu do wprowadzenia dodatkowych nazw miejscowości na wybranych przykładach; pokazanie, jakie były jej efekty i jakie reakcje społeczne temu towarzyszyły, jak również, jaki jest stopień akceptacji mieszkańców Opolszczyzny dla podwójnych nazw na ich terenie.

Proces wprowadzania podwójnego nazewnictwa na Opolszczyźnie (i częściowo w województwie śląskim) zostanie przedstawiony w ujęciu chronologicznym, przy zastosowaniu metody opisowo-analitycznej. Dla pokazania różnych aspektów tego zjawiska w opracowaniu zostanie wykorzystana literatura przedmiotu, rejestry gmin, na których obszarze używane są nazwy w języku mniejszości, a także doniesienia prasowe, relacje i komentarze dostępne w Internecie, jako ważne (choć niekiedy bardzo subiektywne) źródło informacji na temat reakcji mieszkańców na wprowadzanie tablic z dwujęzycznymi nazwami miejscowości na danym terenie. Uwzględnione zostaną też komunikaty $\mathrm{z}$ badań przeprowadzonych przez ośrodek badania opinii publicznej CBOS w kontekście stopnia przyzwolenia na umieszczanie podwójnych nazw na tablicach drogowych.

Ramy czasowe opracowania będą obejmowały okres od 2005 r., tzn. po wejściu w życie Ustawy o mniejszościach narodowych i etnicznych oraz o języku regionalnym, umożliwiającej stawianie tablic drogowych z dwujęzycznymi nazwami miejscowości na obszarach zamieszkanych przez mniejszości narodowe i etniczne, do 2017 r., z uwzględnieniem działań podejmowanych na rzecz nowelizacji tejże ustawy.

Zależy mi na tym, aby, omawiając zagadnienie wprowadzania podwójnego nazewnictwa miejscowości na terenie Opolszczyzny, przedstawić je w całej jego złożoności, zarówno pod względem działań administracyjnych, jak i zróżnicowania postaw społecznych. Zamierzam pokazać, jak trudny i skomplikowany był to proces właśnie z uwagi na jego społeczny odbiór. Chcę zaprezentować szerokie spektrum postaw wobec tego zjawiska, wynikające w dużej mierze ze zróżnicowania składu ludnościowego tego obszaru (jako konsekwencji decyzji podjętych po II wojnie światowej) i - co zrozumiałe - z różnych doświadczeń i zaszłości historycznych oraz kulturowych. 


\section{Rozwiązania europejskie}

Jednym z często powtarzających się argumentów przytaczanych przez mniejszość „za” przyjęciem w Polsce dwujęzycznych nazw miejscowości, było powoływanie się na rozwiązania obowiązujące $w$ tej kwestii w innych krajach. „Dwujęzyczne tablice stały się czymś normalnym i należą do zwykłego porządku świata" - twierdził N. Rasch (TSKN ${ }^{29}$. „Dwujęzyczność w przestrzeni publicznej w Europie nie jest niczym nowym, istnieje właściwie, odkąd ludzie potrafią pisać" - mówił Dawid Smolorz, dziennikarz, pasjonujący się historią Górnego Śląska ${ }^{30}$. Na dowód tego poinformował, iż w swych zbiorach fotograficznych posiada wiele zdjęć tablic drogowych z dwujęzycznymi nazwami miejscowości na pograniczach różnych krajów Europy (m.in. na Litwie, Zaolziu, Węgrzech, w Rumunii). Jego zdaniem w Polsce takie rozwiązania są kojarzone głównie z nagłaśnianiem przez media sporu wokół nazewnictwa pogranicza polsko-litewskiego (chociaż tam chodzi głównie o podwójne nazwy szkół i urzędów). W świadomości opinii publicznej jest to postrzegane jako „oręż walki z przeciwnikiem politycznym, stempel pieczętujący prawo do obecności każdej ze stron na tych ziemiach"31. W przekonaniu Smolorza kwestia poszanowania tradycji i racji drugiej strony występuje jedynie w oficjalnych mowach dyplomatycznych. Zastanawiając się, jakie będą reakcje w Gliwicach po wprowadzeniu podwójnych nazw, Smolorz uważał, iż będzie to poważny sprawdzian tolerancji dla Gliwic: „Chyba żyjąc tutaj zapomnieliśmy, że jest jakieś życie poza Gliwicami”, i przypomniał, że przecież nie wszyscy Niemcy zostali wysiedleni, bądź wyjechali dobrowolnie w okresie powojennym; obecność mniejszości niemieckiej na tym terenie jest teraźniejszością, a nie tylko historią tych ziem² ${ }^{32}$.

Zwolennicy wprowadzenia podwójnego nazewnictwa miejscowości w Polsce często powoływali się na fakt funkcjonowania z powodzeniem dwujęzycznych nazw w wielu innych krajach europejskich; dowodzili, że dwujęzyczne tablice w Unii Europejskiej to standard, i podawali liczne przykłady ich obecności. Artykuły na ten temat zawierały nie tylko dane faktograficzne, ale wzbogacone były też nierzadko materiałami ikonograficznymi ze zdjęciami konkretnych tablic drogowych przy wjeździe do danej miejscowości w różnych krajach Europy. Zwracano uwagę, iż oznakowania z wielojęzycznymi nazwami miejscowości nie są problemem wyłącznie XXI w., ale istniały już przed I i II wojną światową, choć wtedy ich obecność stanowiła raczej wynik działań lokalnej społeczności i nie była regulowana odrębnymi przepisami prawa ${ }^{33}$.

\footnotetext{
29 Dwujęzyczne nazwy miejscowości ustawiono już w 9 gminach województwa opolskiego, 30 IX 2009 r., http://www.nto.pl/serwisy/heimat/art/4129565,dwujezyczne-nazwy-miejscowosci-ustawiono-juz-w-9-g minach-wojewodztwa-opolskiego,id,t.html (dostęp: 15 X 2016 r.).

30 M. Szewczyk, To jest test tolerancji. Pojawiły się polsko-niemieckie nazwy miejscowości (TV), 24 I 2014 r., http://www.24gliwice.pl/wiadomosci/to-test-tolerancji-dla-gliwic-polsko-niemieckie-nazwymiejscowosci-tv/ (dostęp: 17 X 2016 r.)

31 Ibidem.

32 Ibidem.

33 Dwujęzyczne tabliczki w Unii Europejskiej to standard, 29 IV 2015 r., http://www.efhr.eu/2015/04/29/ dwujezyczne-tabliczki-w-unii-europejskiej-to-standard/ (dostęp: 16 X 2016 r.). Por.: S. Łodziński, Refleksyjne dziedzictwo..., s. 18.
} 
W państwach członkowskich UE przywiązuje się dużą wagę do zapewnienia praw mniejszościom narodowym w nich zamieszkującym, o czym świadczą odrębne regulacje prawa międzynarodowego. Kompleksową ochronę zapewnia mniejszościom podpisana w Strasburgu 1 lutego 1995 r. przez Komitet Ministrów Rady Europy Konwencja Ramowa Rady Europy, którą sygnowały wszystkie państwa członkowskie UE (oprócz Francji). Polska podpisała ją w 1995 r., a ratyfikowała w 2000 r. Kwestie umieszczania tradycyjnych nazw lokalnych, nazw ulic oraz innych oznakowań topograficznych o charakterze publicznym w języku mniejszości reguluje art. 11 ust. 3. tejże Konwencji. Zapisy Konwencji Ramowej umożliwiają m.in. wprowadzanie dwujęzycznego nazewnictwa topograficznego w regionach zamieszkanych przez mniejszości narodowe (po spełnieniu warunków określonych stosowną ustawą obowiązującą w danym kraju). Tablice te mają dla mniejszości charakter symboliczny, jako wyraz szacunku dla ich tradycji i języka ${ }^{34}$.

Nierzadko powoływano się na różne regulacje prawne i przepisy obowiązujące w innych krajach. Przykładowo w Austrii prawa mniejszości (w tym prawo do używania dwujęzycznych tablic oraz używanie własnego języka w stosunkach urzędowych) gwarantuje mniejszościom Traktat Państwowy w Sprawie Odbudowy Niezawisłej i Demokratycznej Austrii (1955 r.) oraz ustawa o mniejszościach narodowych (Volksgruppengesetz) z $1976 \mathrm{r} .^{35}$ Pierwsze tablice pojawiły się jednak dopiero w 2000 r. Emocje społeczne wywołało orzeczenie Trybunału Konstytucyjnego z 2001 r., w którym stwierdza się, iż dwujęzyczne tablice z nazwami ulic czy miejscowości mogą być ustawione wówczas, gdy co najmniej 10\% mieszkańców danej gminy posługuje się językiem mniejszości narodowych (uprzednio prawo zezwalało na to, gdy ludność ta stanowiła co najmniej $25 \%$ ogółu mieszkańców) ${ }^{36}$. Obecnie tablice z dwujęzycznymi nazwami można spotkać przede wszystkim na terenie Karyntii i Styrii, gdzie zamieszkuje głównie mniejszość słoweńska oraz w Burgenlandii, zamieszkanej przez mniejszość chorwacką i częściowo węgierską. Interesującą analizę porównawczą uwarunkowań polityki etnicznej Austrii i Polski w kontekście polskiej ustawy o mniejszościach narodowych i etnicznych przeprowadziła Ewa Godlewska, wskazując między innymi na podobieństwa i różnice rozwiązań prawnych w obu krajach ${ }^{37}$.

W Estonii prawo zezwala na używanie dwujęzycznych nazw miejscowości (także ulic, osiedli, dzielnic miast) w językach mniejszości, za które uznaje się: Rosjan (1/4 mieszkańców Estonii), Niemców, Szwedów i Żydów; tablice takie występują w języku rosyjskim i szwedzkim. Podwójne nazewnictwo miejscowości występuje też

\footnotetext{
34 Zob:. Dwujęzyczne tabliczki w Unii...

35 Szerzej na temat mniejszości narodowych zamieszkujących w Austrii i ich praw zob.: E. Godlewska, Prawa językowe mniejszości narodowych w Republice Austrii na przykładzie mniejszości słoweńskiej i chorwackiej, „Annales. Universitatis Mariae Curie-Skłodowska” (sectio K), t. 13 (2006), s. 61-71.

36 Zob.: Dwujęzyczne tabliczki w Unii...

37 E. Godlewska, Polska ustawa o mniejszościach versus rozwiqzania austriackie - analiza porównawcza, [w:] Między lękiem a nadzieja..., s. 119-130.
} 
w wielu krajach nordyckich, np. w Danii (w południowej Jutlandii), Finlandii, Szwecji, Norwegii. W Niemczech tablice dwujęzyczne spotkać można przede wszystkim na terenie Łużyc i w Szlezwiku-Holsztynie. Dwujęzyczne nazwy (włosko-niemieckie) są obecne też w południowym Tyrolu (Górnej Adydze). We Francji, zamieszkanej przez wiele narodowości i grup etnicznych, dwujęzyczne tablice topograficzne funkcjonują w różnych regionach kraju, np. w Alzacji występują (z uwagi na częstą zmianę granic w przeszłości i bliskość Niemiec) w języku francuskim i niemieckim. Tablice dwujęzyczne można też spotkać w Wielkiej Brytanii na terenie Szkocji i Walii, a także w Belgii i na Korsyce.

W Słowenii stosuje się podwójne nazewnictwo na tablicach topograficznych na terenach zamieszkanych przez mniejszości narodowe: Węgrów i Włochów, których języki posiadają status języka oficjalnego. Na Węgrzech dwujęzyczne tablice w językach węgierskim i chorwackim bądź węgierskim i słowackim występują głównie na obszarze pogranicza. Prawa mniejszości regulowane są na Węgrzech w Ustawie o mniejszościach narodowych z 1993 r. Na Słowacji przyjęto zasadę, że wystarczy 20\% mieszkańców, którzy deklarują przynależność do mniejszości narodowej w danej miejscowości, aby można było postawić dwujęzyczne tablice z nazwami miejscowości bądź ulic (z wyjątkiem miejscowości nazwanych od nazwiska zasłużonych Słowaków). Nazwy w języku słowackim i węgierskim spotkać można w południowej Słowacji. Dwujęzyczne nazwy miejscowości występują także w Czechach ${ }^{38}$.

Przykłady te pokazują, że tablice z podwójnymi nazwami miejscowości od dawna funkcjonują z powodzeniem w wielu krajach Europy i na trwałe zadomowiły się w krajobrazie lokalnym, nie budząc sprzeciwu miejscowej ludności; są traktowane jako przejaw poszanowania praw mniejszości narodowych i etnicznych przez dane państwo, a także znak rozpoznawczy, że dany region jest zamieszkiwany przez grupę mniejszościową. W dobie otwartości granic i swobody przemieszczania się stanowi to oznakę akceptacji wielokulturowości regionu, a nie chęci jego zawłaszczenia.

\section{Wokół uregulowań prawnych}

Mniejszość niemiecka jest największą mniejszością narodową w Polsce. Pierwsze przypadki samowolnego stawiania tablic z niemieckimi nazwami miejscowości pojawiły się na Opolszczyźnie już na początku lat 90. ubiegłego wieku (m.in. „Frauenfeld” w Dziewkowicach, „Poppelau” w Popielowie czy „Himmelwitz” w Jemielnicy); wzbudziły jednak natychmiast powszechny sprzeciw wśród miejscowej ludności i lokalnych władz, które nakazywały ich usunięcie. Największą aktywność w działaniach na rzecz wprowadzenia podwójnego nazewnictwa na swoim terenie wykazywała pod koniec lat 90. gmina Bierawa. Zabiegi liderów zamieszkałej w niej mniejszości niemieckiej zmierzały przede wszystkim w kierunku prawnego usankcjonowania możliwości stawiania tablic z podwójnymi nazwami w postaci podjęcia stosownej uchwały przez Radę Gminy ${ }^{39}$.

38 Szerzej na temat praktyki stosowania dwujęzycznych tablic i regulacji prawnych w poszczególnych krajach zob.: Dwujęzyczne tabliczki w Unii..

39 Szerzej na temat inicjatywy radnych bierawskich oraz innych akcji podejmowanych na terenie Opolszczyzny, a także reakcji miejscowej ludności na tego rodzaju praktyki zob.: M. Wagińska-Marzec, Spory o nazwy miejscowości..., s. 21-46. 
Powtarzające się apele środowisk mniejszościowych o stworzenie warunków prawnych umożliwiających korzystanie z przywilejów, jakie obowiązują w innych krajach europejskich, spowodowały, że wreszcie po wielu latach kwestie te zostały ostatecznie uregulowane w Ustawie o mniejszościach narodowych i etnicznych oraz o języku regionalnym, uchwalonej 6 stycznia 2005 r. Prace nad nią trwały de facto od początku lat 90. XX w. Ustawa weszła w życie 1 maja 2005 r.40 Zakończyła ona pewien cykl tworzenia systemu ochrony praw osób należących do mniejszości narodowych i etnicznych; $\mathrm{z}$ jednej strony ujmowała w jednym dokumencie i potwierdzała wcześniejsze regulacje dotyczące tych grup i ich praw, a $\mathrm{z}$ drugiej - $\mathrm{w}$ jakimś zakresie rozszerzała ich przywileje (np. w zakresie dwujęzyczności) ${ }^{41}$. Omawiając proces jej powstawania, Sławomir Łodziński przeanalizował nie tylko kolejne ważniejsze zmiany prawne i uprawnienia mniejszości w okresie przed ustawą i po jej uchwaleniu, ale pokazał też ustawę w kontekście Konwencji Ramowej Rady Europy oraz rozwiązań międzynarodowych ${ }^{42}$.

Kwestie nazewnictwa topograficznego zostały w niej ujęte w rozdziale drugim (art. 12-16) ${ }^{43}$. Ustawa precyzuje m.in., jakie nazwy mogą być wprowadzone jako nazwy dodatkowe (tylko tradycyjne nazwy w języku mniejszości obok urzędowych nazw miejscowości w języku polskim; nie dopuszcza się nazw niemieckich z okresu III Rzeszy; za podstawę nazw historycznych będą przyjmowane wyłącznie nazwy sprzed 1933 r.); określa też szczegółowo m.in. zakres możliwości występowania podwójnych nazw miejscowości (jedynie na terenie gmin zamieszkanych przez mniejszości narodowe i etniczne, wpisanych do Rejestru Gmin prowadzonego przez ministra właściwego ds. wyznań religijnych oraz mniejszości narodowych i etnicznych; dodatkowe nazwy mogą być wprowadzone na terenie całej gminy bądź w poszczególnych miejscowościach); wskazuje warunki niezbędne do ich zastosowania (dodatkowe nazwy w języku mniejszości mogą być ustalone na wniosek rady gminy, jeśli liczba mieszkańców gminy należących do mniejszości nie jest mniejsza niż 20\% ogólnej liczby mieszkańców gminy bądź jeśli w konsultacjach społecznych za wprowadzeniem takiej nazwy opowie się ponad połowa mieszkańców danej miejscowości); ustawa precyzuje też wszelkie kwestie związane z procedurą realizacji wniosku${ }^{44}$.

40 Szerzej o pracach nad projektem ustawy i polemikach z tym związanych zob.: M. Wagińska-Marzec, Problem nazewnictwa na Ziemiach Zachodnich i Północnych w świetle ustawy..., s. 313-322.

\begin{abstract}
41 S. Łodziński, Przed ustawq o mniejszościach..., s. 26.
42 Szersze omówienie kwestii definicyjnych, a także problemów spornych podczas prac legislacyjnych nad ustawa zob. m.in.: G. Janusz, Podmiotowa ochrona w ustawie z dnia 6 stycznia 2005 roku o mniejszościach narodowych i etnicznych oraz o języku regionalnym, [w:] Między lękiem a nadziejq..., s. 15-24; zob. też: M. Wagińska-Marzec, Problem nazewnictwa na Ziemiach Zachodnich i Północnych w świetle ustawy..., s. 309-342; Por.: też uwagi krytyczne o ustawie oraz propozycje dotyczące udoskonalenia ustawy: A. Sadowski, Ustawa o mniejszościach a procesy narodowotwórcze na pograniczach, [w:] Między lękiem a nadzieja..., s. 39-42, 49-51.
\end{abstract}

43 Dz.U. z 2005 r., nr 17, poz. 141.

44 Ustawa precyzowała ponadto: zadania rady gminy dotyczace wprowadzania dodatkowych nazw miejscowości i ulic, wytyczne co do składania wniosków i spraw związanych z procedurą wdrażania dodatkowych nazw, szczegóły odnośnie do wymogów wielkości i stylu czcionki nazw w obu językach na tablicach drogowych, etc. 
Aby wniosek gminy mógł być w ogóle rozpatrywany przez władze, konieczne jest spełnienie dwóch warunków; muszą zostać podjęte: 1) uchwała Rady Gminy o wpisanie do Rejestru Gmin, na których obszarze mają być używane dodatkowe nazwy w języku mniejszości, oraz 2) uchwała Rady Gminy o ustalenie dodatkowej nazwy miejscowości.

Jeśli chodzi o stronę techniczną, to określono, iż dodatkowa nazwa miejscowości na tablicy w języku niemieckim musi mieć ten sam krój i wielkość, co nazwa polska; jedynie w miejscowościach o nazwie dwuczłonowej (np. Wola Biskupska) nazwy mają mieć inne proporcje (zgodnie z rozporządzeniem ministra infrastruktury z sierpnia 2005 r.), tzn. niemiecki odpowiednik ma mieć zmniejszony krój liter o jedną czwartą.

\section{Trudne początki}

W myśl zapisów ustawy starania o ustawienie tablic z dwujęzycznymi nazwami można podjąć bez przeprowadzenia referendum we wszystkich tych gminach, gdzie mniejszość narodowa lub etniczna stanowi (według ostatniego spisu ludności) co najmniej $20 \%$ ogółu mieszkańców ${ }^{45}$. Warunek przekroczenia progu $20 \%$ uprawniający do wprowadzenia dodatkowych nazw miejscowości w języku mniejszości bez konieczności konsultacji społecznych spełnia na Opolszczyźnie 28 gmin. Są to gminy: Biała, Bierawa, Chrząstowice, Cisek, Dobrodzień, Dobrzeń Wielki, Głogówek, Izbicko, Jemielnica, Kolonowskie, Komprachcice, Krzanowice, Lasowice Wielkie, Leśnica, Łubniany, Murów, Olesno, Pawłowiczki, Polska Cerkiew, Prószków, Radłów, Reńska Wieś, Strzeleczki, Tarnów Opolski, Turawa, Ujazd, Walce i Zębowice. Wśród nich są 22 gminy, w których używa się języka niemieckiego jako pomocniczego ${ }^{46}$.

Jedną z pierwszych gmin, które złożyły oficjalny wniosek do Urzędu Wojewódzkiego w Opolu o wprowadzenie dodatkowej nazwy niemieckiej dla miejscowości na jej terenie, była gmina Radłów koło Olesna w województwie opolskim. Warto podkreślić, że urząd wójta sprawował wówczas Włodzimierz Kierat (Polak), wybrany z listy komitetu mniejszości niemieckiej. Wniosek złożony 13 czerwca 2006 r. dotyczył 12 miejscowości spełniających wymogi określone ustawą. Po uzyskaniu pozytywnej oceny Wojewody Opolskiego, został on przekazany do MSWiA. Ministerstwo wstrzymało się jednak początkowo z wydaniem opinii ze względu na uchybienia formalne (chodziło o niezgodność liczby ogółu mieszkańców gminy podanej we wniosku z danymi, które podawał GUS). Skorygowanie błędu było stosunkowo łatwe do usunięcia, toteż wniosek uzyskał wkrótce pozytywną opinię MSWiA. Gmina Radłów została wpisana do Rejestru 22 grudnia 2006 r.; zezwolenie na postawienie

45 Pełnomocniczka Wojewody Warmińsko-Mazurskiego ds. mniejszości narodowych i etnicznych w Olsztynie, Joanna Wańkowska-Sobiesiak, na początku października 2006 r. oznajmiła, że wprowadzenie w życie ustawy o mniejszościach narodowych i etnicznych i języku regionalnym nie spowodowało „konieczności zastosowania w woj. warmińsko-mazurskim podwójnego nazewnictwa miejscowości”. Żadna z gmin bowiem nie spełniała wymogów określonych w ustawie uprawniających do wprowadzenia podwójnych nazw (nie przekroczono wymaganego progu 20\% ogółu mieszkańców danej gminy; za podstawę przyjęto wówczas wyniki ostatniego Spisu Powszechnego z 2002 r.)

46 Szerzej zob. Tablice z nazwami miejscowości w jęyku polskim i niemieckim (24), $27 \mathrm{~V} 2015 \mathrm{r}$. http://pl.delfi.lt/aktualia/polska/tablice-z-nazwami-miejscowosci-w-jezyku-polskim-i-niemieckim. d?id=68075068 (dostęp: 15 X 2016 r.). 
tablic dwujęzycznych otrzymało wówczas 11 wsi i osad ${ }^{47}$; nie wprowadzono dodatkowych nazw dla 24 części wsi, osad, przysiółków i osady leśnej.

W rzeczywistości do postawienia dwujęzycznych tablic doszło jednak dopiero po niemal dwóch latach od wydania decyzji. Powodem tego stanu rzeczy był problem z pisownią jednej z nazw miejscowości na terenie gminy; chodziło o Biskupskie Drogi/Strassenkrug, którą zatwierdzono dopiero 29 października 2007 r. Na długi proces realizacji wpływ wywarły również względy proceduralne (podpisanie umowy z ministerstwem na sfinansowanie tablic nastąpiło dopiero w marcu 2008 r., do tego doszło jeszcze ogłoszenie przetargu publicznego, etc.). Ostatecznie tablice postawiono w połowie września $2008 \mathrm{r}^{48}$

W opinii Norberta Rascha (członka zarządu TSKN) to „przetarcie szlaków” miało duże znaczenie dla środowiska mniejszości, gdyż ośmielało i zachęcało innych do składania podobnych wniosków. Rasch wspominał, iż pierwsze tablice były odsłaniane z wielką pompą, przy dużym udziale samorządowców, co uważał za rzecz pozytywna, gdyż została $w$ ten sposób przełamana „pewna bariera"49. Początkowo miały miejsce przypadki zamalowywania tablic (dwie tablice zamalowano w Radłowie, jedną w Kolonii Biskupiej). Wójt zapewnił, że farbę zmyje i poczeka na dalszy rozwój wypadków; zdarzenia nie zgłosił na policję ${ }^{50}$. Wiceprzewodniczący zarządu TSKN, poseł mniejszości niemieckiej w Sejmie RP, Ryszard Galla, który uczestniczył w hucznym odsłonięciu tablicy, sugerował, że być może powodem owego „wandalizmu” było właśnie zbytnie nagłośnienie całej uroczystości. Jego zdaniem najlepszą reakcją na tego rodzaju działania jest „spokojnie przeczekać” i zadeklarował wsparcie wójta w tej sytuacji ${ }^{51}$.

Jeden z liderów mniejszości niemieckiej w Tarnowie Opolskim, Franz Dylla, zauważył, że na początku odnotowano wiele przypadków niszczenia tablic; później było już jednak „spokojniej”. W jego opinii sprawcami byli raczej frustraci, odreagowujący w ten sposób np. utratę pracy czy też inne niepowodzenia życiowe, niż „wrogowie Niemców”52. Podobnie uważał Rafał Bartek, dowodząc, iż obecnie nie ma masowej niechęci Polaków do tablic dwujęzycznych ani też wzmożonej kampanii przeciwko nim. Można zaobserwować, że kolejne nazwy są pokrywane „tą samą farbą i tą samą ręką". W przekonaniu Bartka najważniejsze, by te „malunki” szybko usuwać i nie dać satysfakcji ich wykonawcom. Jego zdaniem nieskuteczna jest natomiast taktyka „cichego" ustawiania tablic, gdyż to raczej „rozzuchwala niszczycieli”33.

47 Gmina złożyła 12 wniosków o ustalenie dodatkowych nazw miejscowości w języku niemieckim, jednak Komisja Nazw Miejscowości i Obiektów Fizjograficznych, wydająca opinię na temat proponowanych nazw, zaopiniowała pozytywnie 11 nazw.

48 P. Popieliński, Wpływ ustawy o mniejszościach narodowych i etnicznych oraz o języku regionalnym na funkcjonowanie środowiska mniejszości niemieckiej w Polsce, [w:] Między lękiem a nadziejq..., s. 219.

49 Zob.: Dwujęzyczne nazwy miejscowości ustawiono już w 9 gminach...

50 Zob.: Niemieckie nazwy miejscowości zamazywane, 15 IX 2008 r., http://wiadomosci.gazeta.pl/wiadomosci/1,114873,5698016,Niemieckie_nazwy_miejscowosci_zamazywane.html (dostęp: 20 X 2016 r.).

51 Ibidem

52 Zob.: Dwujęzyczne nazwy miejscowości ustawiono już w 9 gminach...

53 Ibidem 
Komentując akty niszczenia tablic z podwójnymi nazwami miejscowości, socjolog Danuta Berlińska zauważyła, że w wielu regionach wielokulturowych spotyka się osoby (lub grupy), które są nastawione negatywnie do jawnego manifestowania owej wielokulturowości. Efektem tego jest często właśnie np. „walka za pomocą farby” z wielojęzycznymi nazwami miejscowości ${ }^{54}$. Potwierdzała również tezę, iż wiele tablic jest zamalowywanych „tymi samymi rękami”, co świadczy o tym, że grupa niechętnych tablicom osób jest stosunkowo nieliczna („kilku frustratów”). Brak reakcji i nieprzywracanie tablic do ich stanu pierwotnego mogłoby oznaczać, że jest społeczne przyzwolenie na takie zachowania. Danuta Berlińska twierdziła, że takich reakcji można się było spodziewać; uważała jednak, że wójt powinien szybko na to reagować (wyczyścić tablice lub postawić nowe), aby „wandale nie czuli się bezkarni”, nie można bowiem dopuszczać do tego, aby skutki ich działania były widoczne: „wówczas się zrażą i znudzą” - mówiła ${ }^{55}$. Tablice powinny być, jej zdaniem, pokryte specjalną powłoką, by umożliwić szybkie i skuteczne zmycie farby. Rzuciła nawet pomysł, by stworzyć specjalny fundusz na remont tablic. Podkreśliła, że to nie tylko sprawa mniejszości, ale również sprawa większości, która ustanowiła prawo dające możliwość ustawiania tablic dwujęzycznych i która powinna to prawo szanować ${ }^{56}$. Sugerowała wręcz, że niezbędne jest przy tym współdziałanie mieszkańców regionu. Powinni oni powiadamiać miejscowe władze o takich przypadkach, by można było szybko podjąć stosowne krokij7 ${ }^{57}$

Drugą gminą, która wystąpiła w 2006 r. z wnioskiem o wprowadzenie dodatkowej nazwy, była Leśnica. Wniosek obejmował 12 miejscowości na terenie gminy; w pierwszej wersji został jednak zaopiniowany przez wojewodę negatywnie ze względu na uchybienia formalne; chodziło o to, że jedna z proponowanych przez mniejszość nazw pochodziła z 1936 r., co było niezgodne z zapisem ustawy. Problem dotyczył miejscowości Góra Świętej Anny. Proponowaną przez mniejszość nazwą była: Sankt Annaberg, natomiast jej historyczna nazwa brzmiała: Annaberg ${ }^{58}$. Innym powodem odrzucenia wniosku był brak konsultacji z mieszkańcami, a także brak wymaganej uchwały Rady Gminy o wprowadzenie dodatkowej nazwy miejscowości. Wniosek został więc przez wojewodę odesłany do uzupełnienia. Oficjalnie gmina Leśnica uzyskała zgodę na wprowadzenie niemieckich nazw 11 kwietnia 2008 r.; otrzymały je miasto Leśnica oraz 11 wsi; nie wprowadzono dodatkowych nazw dla 9 części wsi, przysiółków i osad. Nota bene jako odpowiednik nazwy Góra Świętej Anny przyjęto: Sankt Annaberg ${ }^{59}$.

54 Ibidem.

55 Zob.: Niemieckie nazwy miejscowości zamazywane..

56 Ibidem.

57 Zob.: Dwujęzyczne nazwy miejscowości ustawiono już w 9 gminach...

58 Z rozmów przeprowadzonych z dr Moniką Choroś i mgr Łucją Jarczak, pracownikami naukowymi Instytutu Śląskiego w Opolu, specjalistkami w zakresie nazewnictwa na Śląsku, wynika, że 7 gmin opolskich zwróciło się w tym okresie do Instytutu Śląskiego w Opolu z prośbą o zweryfikowanie poprawności proponowanych przez nie nazw niemieckich jako nazw dodatkowych.

59 Zob.: Dwujęzyczne nazewnictwo geograficzne w Polsce, http://www.wikiwand.com/pl/Dwujęzyczne_nazewnictwo_geograficzne_w_Polsce (dostęp: 10 XI 2017 r.). 
Było rzeczą znamienną, że w pierwszym okresie do Urzędu Wojewody Opolskiego złożono stosunkowo mało wniosków w sprawie wprowadzenia dodatkowych nazw miejscowości, mimo że były ku temu warunki tak bardzo wyczekiwane przez mniejszość. Przedtem przedstawiciele mniejszości zapewniali, że „wszystko jest już przygotowane i tylko czeka na odpowiednie regulacje prawne”. Być może chciano bardziej starannie przygotować wnioski pod względem wymogów formalnych, by nie narazić się na odmowę, a być może obawiano się mimo wszystko reakcji społecznych.

Dziwić też może fakt, że w początkowej fazie zabrakło również wniosku gminy Bierawa (w której ok. 80\% mieszkańców stanowili autochtoni; mniejszość niemiecka była tu większością), a przecież była to gmina, od której niemal wszystko się zaczęło, która najbardziej energicznie i najgłośniej domagała się wprowadzenia na swoim terenie podwójnych nazw. Próbując dociec przyczyny tego zjawiska, uzyskałam wyjaśnienie, że w międzyczasie nastąpiły zmiany w składzie Rady Gminy (uprzednio na 20 radnych 15 było członkami TSKN; później proporcje w składzie Rady uległy zmianie i mniejszość niemiecka nie stanowiła już w niej większości). Nastąpiły też zmiany personalne w Radzie; funkcję przewodniczącego przestał pełnić Joachim Niemann - niezwykle aktywny lider mniejszości niemieckiej w Opolskiem, jeden z inicjatorów tzw. apelu o utworzenie prawnych warunków do wprowadzenia dwujęzycznych nazw miejscowości ${ }^{60}$. Trzeba przypomnieć, że Niemann już 14 lutego 1998 r. wystąpił z wnioskiem do Urzędu Wojewódzkiego w Opolu (a także do prezydenta RP, marszałków Sejmu i Senatu oraz do premiera) o wprowadzenie na terenie gminy nazw niemieckich; do wniosku dołączono wówczas propozycje niemieckich odpowiedników nazw, z których większość była „przechrztami” z okresu III Rzeszy). Nowym przewodniczącym Rady został Ryszard Gołębowski, dotychczasowy zastępca wójta gminy Bierawa.

Rozdźwięk pomiędzy wcześniejszym, niezwykle stanowczym domaganiem się podwójnego nazewnictwa i zapewnieniami, że „wszystko jest już gotowe” i zaraz po uchwaleniu ustawy o mniejszościach będzie można natychmiast wprowadzać tablice drogowe z dodatkowymi nazwami, a późniejszą niewielką liczbą zgłoszonych oficjalnie wniosków był zastanawiający. Być może wynikało to po części z faktu, że ustawa określała wyraźnie, iż nie mogą to być nazwy z okresu 19331945, a jedynie nazwy historyczne. A tych z kolei mniejszość nie znała. Ci, którzy mieszkali na tym terenie przed wojną i w czasie jej trwania, pamiętali jedynie nazwy, które wówczas obowiązywały (czyli nazwy wprowadzone przez nazistów). Stąd też prawdopodobnie zainteresowanie wprowadzeniem dodatkowych nazw, które de facto były im obce, wyraźnie zmalało. Zjawisko to wymagałoby jednak bardziej pogłębionych badań.

Po Radłowie/Radlau do wprowadzenia niemieckich nazw przygotowywały się kolejne gminy: Cisek (wpisano do Rejestru: 11 października 2007 r.), Leśnica (11 kwietnia 2008 r.), Tarnów Opolski (14 kwietnia 2008 r.), Chrząstowice (20 maja 2008 r.), Izbicko 
(20 maja 2008 r.), Dobrodzień (4 lipca 2008 r.), Jemielnica (14 listopada 2008 r.), Kolonowskie (14 listopada 2008 r. $)^{61}$.

Warto podkreślić, że na terenie Górnego Śląska pierwszą gminą, którą wpisano do Rejestru (11 kwietnia 2008 r.), była gmina Rudnik (pow. raciborski, woj. śląskie); tablicę $\mathrm{z}$ dodatkową nazwą $\mathrm{w}$ języku niemieckim postawiono $\mathrm{w}$ niej we wsi Łubowice/Lubowitz. Jest to o tyle istotnie, że miejscowość ta nie spełniała de facto wymogów formalnych, gdyż mniejszość niemiecka nie przekroczyła tam wymaganego progu $20 \%$ ogółu mieszkańców gminy (stanowiła zaledwie 13,4\% wg Spisu Powszechnego z 2002 r.). Było to jednak możliwe dzięki konsultacjom społecznym, a także z uwagi na znaczenie miejscowości jako miejsca urodzin ważnego dla kultury niemieckiej poety górnośląskiego epoki romantyzmu, Josefa von Eichendorffa; z tego względu miejscowość jest odwiedzana przez wielu Niemców; działa w niej też Górnośląskie Centrum Kultury i Spotkań noszące jego imię. Uroczyste odsłonięcie tablic miało miejsce 4 września 2008 r. ${ }^{62}$

W gminie Komprachcice TSKN wystąpiło do Rady Gminy z wnioskiem o zgodę na wprowadzenie dwujęzycznych tablic w kwietniu 2008 r.; wniosek został jednogłośnie przyjęty. W gminie na nieco ponad 11 tys. mieszkańców aż 3260 osób deklarowało przynależność do mniejszości niemieckiej, co stanowiło niemal 29\% społeczności (w myśl ustawy o mniejszościach narodowych znacząco przekroczono zatem przewidywany próg $20 \%$ lokalnej społeczności, uprawniający do postawienia tablic dwujęzycznych bez konieczności przeprowadzenia społecznych konsultacji). Zdaniem posła Ryszarda Galla gmina Komprachcice nie jest typową gminą mniejszościową; jest bardzo zróżnicowana pod względem narodowościowym³ ${ }^{63}$. Stąd też do problemu podwójnego nazewnictwa miejscowości podchodzono, jak mówił, bardzo ostrożnie, szukając kompromisu i akceptacji większości, aby uniknąć w przyszłości protestów bądź niechęci ze strony ewentualnych przeciwników tablic ${ }^{64}$. Wątpliwości mieszkańców budził niemiecki odpowiednik nazwy Polskiej Nowej Wsi (Polnisch Neudorf); udało się jednak przekonać miejscową ludność, że tak brzmiała właśnie jej nazwa historyczna.

61 Na Pomorzu do rejestru gmin, na których obszarze są używane nazwy w języku mniejszości, najwcześniej wpisano dwie gminy: Stężycę (14 XI 2007 r.) - 54 kaszubskie nazwy wsi i części wsi; oraz Chmielno (3 XII 2007 r.) - 31 kaszubskich nazw wsi, czéści wsi, osad, kolonii, zob.: Rejestr gmin, na których obszarze używane sq języki mniejszości, http://mniejszosci.narodowe.mswia.gov.pl/mne/rejestry/rejestr-gmin/6794,Rejestr-gmin-na-ktorych-obszarze-sa-uzywane-nazwy-w-jezyku-mniejszosci.html (dostęp: 24 X 2017 r.). W 2013 r. tradycyjne kaszubskie nazwy miejscowości były już ustanowione w 10 gminach. M. Węsierski informował, że na Pomorzu przybywa dwujęzycznych nazw miejscowości, można je bowiem wprowadzić nawet bez konsultacji społecznych (jeśli w danej gminie ponad 20\% osób zadeklaruje posługiwanie się językiem kaszubskim); na Pomorzu tych gmin jest 19. Szerzej zob.: M. Węsierski, Na Kaszubach przybywa dwujęzycznych nazw miejscowości. Gminy za nowe tablice nie płacq, „Dziennik Bałtycki", z 7 III 2013 r.

62 Zob.: P. Popieliński, op. cit., s. 219-220.

63 Zob.: Tablice $z$ podwójnymi nazwami miejscowości stanq $w$ gminie Komprachcice do końca maja, 26 V 2010 r., http://www.nto.pl/serwisy/heimat/art/4152709,tablice-z-podwojnymi-nazwami-miejscowo sci-stana-w-gminie-komprachcice-do-konca-maja,id,t.html (dostęp: 20 X 2016 r.). 
Ostatecznie niemieckie nazwy w gminie Komprachcice wprowadzono 1 grudnia 2009 r. dla 10 wsi oraz jednego przysiółka; otrzymały je: Chmielowice - Chmiellowitz, Domecko - Dometzko, Dziekaństwo - Dziekanstwo, Komprachcice - Comprachtschütz, Ochodze - Ochotz, Osiny - Rothhaus, Polska Nowa Wieś - Polnisch Neudorf, Pucnik - Simsdorf (przysiółek), Wawelno - Bowallno, Żerkowice - Zirkowitz. Nie wprowadzono dodatkowych niemieckich nazw dla trzech części wsi i jednej osady ${ }^{65}$. Do końca maja 2010 r., wymieniono tablice drogowe we wszystkich 9 sołectwach gminy; koszt wymiany wyniósł ok. 24 tys. zł; środki na ten cel pochodziły $\mathrm{z}$ budżetu państwa ${ }^{6}$.

Do końca 2009 r. w ministerialnym Rejestrze Gmin, w których wprowadzono już podwójne nazwy miejscowości, znalazło się 21 gmin w całej Polsce, z tego 15 na terenie województwa opolskiego; łącznie było już 197 nazw niemieckich ${ }^{67}$. Komentując ten fakt, Rafał Bartek, przewodniczący TSKN na Śląsku Opolskim, stwierdził, iż oznacza to, że mniejszość niemiecka jest nie tylko największą mniejszością, ale też najbardziej dynamicznie korzystającą ze swych praw ${ }^{68}$. Zwrócił przy tym uwagę, iż wpis do Rejestru nie oznacza jeszcze natychmiastowego postawienia tablic; cała procedura z tym związana trwa bowiem około roku; do końca września 2009 r. tablice z dwujęzycznymi nazwami postawiono już w 9 gminach województwa opolskiego ${ }^{69}$.

Gminą, która zgodnie z wymogami ustawy musiała przeprowadzić konsultacje społeczne, aby móc wprowadzić na swym terenie podwójne nazwy miejscowości, były m.in. Sośnicowice w powiecie gliwickim (województwo śląskie). Gmina liczy 8 sołectw; zamieszkuje ją ok. 8100 mieszkańców. Michał Szewczyk zwrócił uwagę, że język niemiecki był tu obecny od wieków, a w okresie powojennym przeplatał się z polszczyzną; nie był jednak wyznacznikiem rzeczywistej tożsamości narodowej. Zdarzało się bowiem, że w domu rozmawiano po polsku, ale identyfikowano się z niemieckością; tę złożoność wielokulturową daje się zaobserwować, jego zdaniem, również obecnie. W ostatnim spisie powszechnym (2011 r.) narodowość niemiecką zadeklarowało zaledwie $6 \%$ mieszkańców gminy ${ }^{70}$. To głównie z ich inicjatywy wyszła propozycja wprowadzenia podwójnych nazw. Pierwsze konsultacje społeczne w tej sprawie miały miejsce już w październiku 2005 r., a więc parę miesięcy po zatwierdzeniu ustawy o mniejszościach narodowych i etnicznych. W konsultacjach społecznych wzięło wówczas udział ok. 30\% mieszkańców; większość opowiedziała się „za” podwójnym nazewnictwem; negatywnie ustosunkowali się do tego jedynie mieszkańcy Bargłówki i Tworogu Małego. Sprawa jednak na dłuższy czas przycichła,

Zob.: Dwujęzyczne nazewnictwo geograficzne...

66

Ibidem.

67 P. Popieliński, op. cit., s. 220.

68 Zob.: Dwujęzyczne nazwy miejscowości ustawiono już w 9 gminach...

69 Ibidem.

M. Szewczyk, op. cit. 
a urzędnicy nie podejmowali żadnych dalszych kroków celem wdrożenia związanej $\mathrm{z}$ tym procedury.

Działania w tym kierunku wznowiono dopiero w 2012 r., odkąd sprawą tą zainteresował się, na skutek powtarzających się pytań, nowy burmistrz Sośnicowic, Marcin Stronczyk. Wystosowano wówczas odpowiedni wniosek do Ministerstwa Administracji i Cyfryzacji, gdzie inicjatywa mieszkańców została zaopiniowana pozytywnie. W rezultacie 10 października 2013 r. w gminie Sośnicowice wprowadzono 6 niemieckich nazw oraz jedną następnego roku (1 października 2014 r.). Podwójne nazwy otrzymały miejscowości: Kozłów - Kozlow, Łany Wielkie - Lona Lany, Rachowice - Rachowitz, Sierakowice - Schierakowitz, Sośnicowice - Kieferstädtel, Smolnica - Smolnitz oraz Trachy - Althammer. Zgodnie z wolą mieszkańców nie wprowadzono podwójnych nazw w dwóch sołectwach: Tworóg Mały i Bargłówka ${ }^{71}$, a także w kilku częściach wsi i kolonii. Tablice zostały postawione w pierwszej kolejności na drogach gminnych i powiatowych, później na wojewódzkich.

W opinii działaczy mniejszości niemieckiej na Śląsku Opolskim w kilku gminach zamieszkanych przez mniejszość zbyt mało zrobiono na rzecz wprowadzenia podwójnych nazw. Jako przykład Rafał Bartek wymienił Polską Cerekiew (dopiero w 2011 r. wprowadzono w niej 12 niemieckich nazw; nie wprowadzono dodatkowych nazw dla: 1 wsi, 5 części wsi oraz 3 przysiółków wsi) ${ }^{72}$ oraz Reńską Wieś (również dopiero w $2011 \mathrm{r}$. wprowadzono 15 niemieckich nazw dla wsi; nie wprowadzono dodatkowych nazw dla 2 części wsi i 4 przysiółków wsi) ${ }^{73}$. Komentując ten fakt, Bartek przypomniał, że „tablice są wizualnym symbolem obecności mniejszości na naszym terenie", o czym samorządowcy najwyraźniej zapomnieli ${ }^{74}$.

W 2012 r. pojawiły się głosy, że mniejszość niemiecka chce szybko postawić tablice z polsko-niemieckimi nazwami miejscowości, gdyż obawia się wyników spisu powszechnego z marca 2011 r. Zdaniem posła Patryka Jakiego (Solidarna Polska) środowiska mniejszości niemieckiej obawiały się, że wyniki spisu wykażą, iż w niektórych gminach mniejszość stanowi mniej niż owe ustawowo uchwalone $20 \%$ ogółu ludności, co spowoduje, że otrzymają nakaz przeprowadzenia konsultacji społecznych, by przeforsować niemieckie nazwy na tablicach ${ }^{75}$. Poseł wystąpił w związku z tym do ministra administracji i cyfryzacji oraz wojewody opolskiego z wnioskiem o wstrzymanie wydawania zezwoleń na dwujęzyczne tablice do momentu ogłoszenia wyników spisu powszechnego. Przedstawiciel mniejszości Damian Hutsch nie przejawiał tego rodzaju obaw; uważał, że wokół tego narosło zbyt wiele kontrowersji. W jego przekonaniu

71 Zob.: Podwójne nazwy miejscowości na terenie powiatu gliwickiego, 7 I 2014 r., http://miastoknurow. pl/30401.podwojne-nazwy-miejscowosci-na-terenie-powiatu-gliwickiego.html (dostęp: 25 X 2017 r.).

72 Zob.: Dwujęzyczne nazewnictwo geograficzne...

73 Ibidem.

74 Zob.: Dwujęzyczne nazwy miejscowości ustawiono już w 9 gminach...

75 Niemieckie nazwy miejscowości w Opolskiem. Zmiany przez spis powszechny?, 21 III 2012 r. http://wiadomosci.onet.pl/opole/niemieckie-nazwy-miejscowosci-w-opolskiem-zmiany-przez-spispowszechny/85pmy (dostęp: 26 X 2017 r.). 
problem polegał na tym, że wyniki te „do czegoś obligowały”. Z Ministerstwa Administracji i Cyfryzacji (MAC) otrzymał jednocześnie zapewnienie, że dwujęzyczne tablice pozostaną nawet w tych gminach, w których liczba mniejszości niemieckiej spadnie poniżej owych $20 \%{ }^{76}$.

W 2012 r. tablice dwujęzyczne stały już w następujących gminach (w kolejności według liczby miejscowości, w których ustawiono tablice): Biała (Zülz) - w 30 miejscowościach, Dobrodzień (Guttentag) - 25, Głogówek (Oberglogau) - 22, Strzeleczki (Klein Strelitz) - 19, Prószków (Proskau) - 15, Reńska Wieś (Reinschdorf) - 15, Cisek (Czissek) - 14, Lasowice Wielkie (Gross Lassowitz) - 13, Murów (Murow) - 13, Leśnica (Leschnitz) - 12, Polska Cerekiew (Groß Neukirch) - 12, Radłów (Radlau) - 11, Izbicko (Stubendorf) - 11, Łubniany (Lugnian) - 11, Turawa (Turawa) - 11, Bierawa (Birawa) - 10, Komprachcice (Comprachtschütz) - 10, Pawłowiczki - 10, Ujazd (Ujest) - 10, Zębowice (Zembowitz) - 10, Chrząstowice (Chronstau) - 9, Dobrzeń Wielki (Groß Döbern) - 9, Gogolin - 9, Walce (Walzen) - 9, Tarnów Opolski (Tarnau) - 8, Sośnicowice (Kieferstädtel) - 7, Jemielnica (Himmelwitz) - 6, Popielów (Poppelau) - 6, Krzanowice (Kranowitz) - 5, Kolonowskie (Colonnowska) - 4, Strzelce Opolskie - 3), Rudnik - $1^{77}$. Z tego wynika, że najwięcej tablic dwujęzycznych postawiono w miejscowościach na terenie gmin: Biała, Dobrodzień, Głogówek, Strzeleczki. Można też zauważyć, iż w pewnych gminach wprowadzono podwójne nazwy tylko w niektórych miejscowościach (wsiach); samo miasto gminne nie przyjęło dodatkowej nazwy niemieckiej, np. Gogolin, Strzelce Opolskie, Rudnik,

Dość dziwny wydaje się fakt, że w gminie Popielów, zamieszkałej przez ludność pochodzenia niemieckiego oraz ludność dolnośląską (w części byłego powiatu brzeskiego), która praktycznie jako pierwsza zainicjowała samoczynne akcje stawiania dwujęzycznych tablic, radni zadecydowali o wprowadzeniu dodatkowych nazw niemieckich de facto dopiero w 2014 r. Pod koniec września 2014 r. wprowadzono wówczas 6 niemieckich nazw dla wsi: Kaniów - Hirschfelde, Lubienia - Sacken, Nowe Siołkowice - Neu Schalkowitz, Stare Siołkowice - Alt Schalkowitz, Popielowska Kolonia - Klink, Popielów - Poppelau; nie uchwalono natomiast dodatkowych nazw dla pozostałych 6 wsi, 2 części wsi, jednej osady i 9 przysiółków wsi. W tych miejscowościach sprawa jest otwarta, jak oznajmił wójt Popielowa Dionizy Duszyński: „Ludzie chcą tam poczekać, nie są jeszcze do końca zdecydowani"78.

\section{Brak zgody na podwójne nazwy}

Nie wszędzie była pełna akceptacja lokalnej społeczności na wprowadzanie dwujęzycznych nazw. Taka sytuacja miała miejsce w miejsko-wiejskiej gminie Ozimek 
(woj. opolskie). Zamieszkała na terenie gminy mniejszość niemiecka wystosowała w 2013 r. do marszałek Sejmu (wówczas Ewy Kopacz) pismo w sprawie „braku zgody" na tablice dwujęzyczne na terenie tejże gminy. Zwrócono w nim uwagę, że mimo pozytywnego wyniku konsultacji społecznych, w których mieszkańcy siedmiu miejscowości: Szczedrzyka, Schodni, Pustkowa, Krasiejowa, Mnichusa, Krzyżowej Doliny oraz Chybia, wypowiedzieli się za wprowadzeniem dwujęzycznych tablic, radni Ozimka nie przyjęli stosownej uchwały w tej sprawie.

Szef lokalnego TSKN Bernard Gaida wyraził ubolewanie z tego powodu, mówiąc: „Okazało się, że w demokratycznym głosowaniu radnych można zablokować wolę mieszkańców wyrażoną również demokratycznie, bo w formie konsultacji"79. Uważał, że jest to oznaka braku akceptacji dla praw mniejszości w ogóle, nie tylko niemieckiej. Zwrócił uwagę, iż jest to niezgodne z wolą ustawodawcy, który dawał mniejszościom określone ustawowo przywileje. Od marszałek Sejmu oczekiwano nie tyle zajęcia stanowiska w tej sprawie, ile „wykładni” przepisów ustawy o mniejszościach. W piśmie zaznaczono, że projekt uchwał dotyczących polsko-niemieckich tablic miejscowości został odrzucony przez radnych Ozimka podczas sesji w styczniu 2013 r.; w głosowaniu nad przyjęciem uchwały „za” tablicami opowiedziało się siedmiu radnych, przeciwnych było dwunastu radnych, a dwie osoby wstrzymały się od głosu ${ }^{80}$. Przewodniczący Rady Gminy i miasta Ozimek Joachim Wiesbach głosując „za” wprowadzeniem podwójnych nazw, przekonywał: „Tak rozumiem demokrację: skoro pytamy mieszkańców, czy chcą takich tablic, oni w konsultacjach odpowiadają twierdząco, to należy ich wolę uszanować"81.

Radni głosujący „przeciw” uchwale tłumaczyli z kolei, że w swej decyzji kierowali się m.in. niską frekwencją podczas konsultacji: „Skoro mieszkańcy nie przyszli na konsultacje, by opowiedzieć się za lub przeciw tablicom, to widać są im niepotrzebne" - stwierdził jeden z radnych, Krzysztof Kleszcz ${ }^{82}$. Był ponadto przekonany, że sto procent jego wyborców oczekiwałoby, aby tak właśnie zagłosował w tej sprawie. Jego zdaniem dwujęzyczne tablice mogłyby spowodować niepokoje społeczne, czego dowodem może być fakt, że już samo głosowanie wywołało dyskusję w mediach. Komentując odmowną decyzję radnych Ozimka, Ryszard Galla uznał, że jest to przejaw braku poszanowania dla woli ludzi, którzy opowiedzieli się za tablicami, a także brak akceptacji wielokulturowości ${ }^{83}$.

Specjalne oświadczenie w tej sprawie złożył też zarząd TSKN na Śląsku Opolskim; Norbert Rasch w imieniu TSKN przekonywał, że „Tablice są szansą, a nie zagrożeniem. Są elementem promocji wielojęzyczności. Wielojęzyczność jest stanem

79 Spór o dwujęzyczne nazwy na Opolszczyźnie, 4 II 2013 r., http://www.polskieradio.pl/5/3/Artykul/ 775720,Spor-o-dwujezyczne-nazwy-na-Opolszczyznie (dostęp: 12 X 2016 r.)

80 Ibidem

81 Ibidem

82 Ibidem

83 Ibidem. 
przyrodzonym w Europie i na świece. To nie mniejszości mają być wielojęzyczne, lecz całe społeczeństwa"84. Nadmienił przy tym, iż według jego rozeznania tablice z dwujęzycznymi nazwami znajdują się już w ok. 300 miejscowościach na terenie Śląska Opolskiego. Był to przekonujący argument, choć trudno ocenić, w jakim stopniu skuteczny.

Mniejszość niemiecka w gminie Ozimek nie zamierzała ustąpić i 31 marca 2016 r. TSKN skierowało kolejny wniosek do Rady Miejskiej o „ponowne podjęcie czynności zmierzających do wprowadzenia podwójnego nazewnictwa miejscowości gminy Ozimek" ${ }^{\prime 85}$. Za względu na argumentację w nim zawartą warto szerzej omówić ów dokument. Uzasadniano w nim, iż dotychczasowe rozstrzygnięcia w tej sprawie nie tylko były „głęboko krzywdzące” dla ludności rodzimej mieszkającej na tym terenie, ale nie uwzględniały też oczekiwań przedstawicieli ludności napływowej oraz ich potomków. Przytaczano argument, że obecnie wielokulturowość stała się „wizytówką" wielu regionów Europy; wskazywano, iż często nawet na terenach, gdzie przedstawiciele mniejszości stanowią jedynie niewielki procent mieszkańców, z dumą podkreśla się wielokulturową przeszłość. Uważano zatem, że należy wznowić działania zmierzające do wprowadzenia na terenie gminy Ozimek obok nazw współczesnych także nazw historycznych.

W piśmie odwoływano się do podnoszonych już wcześniej argumentów, uważając, iż chociaż zostały uprzednio „opacznie zrozumiane” bądź „zignorowane”, powinny być brane pod uwagę i uwzględnione w dyskusji przy rozpatrywaniu niniejszego wniosku. Wskazano na fakt niezwykle istotny dla ukazania tożsamości historycznej regionu województwa opolskiego, mianowicie, że historyczne nazwy miejscowości na tym terenie najlepiej świadczą o wielorakich wpływach różnych okresów kulturowych tych ziem na przestrzeni dziejów. W wielu nazwach widać wyraźnie niemieckie i słowiańskie korzenie (np. Szczedrzyk - pierwotnie Sczedrzik, Schodnia - pierwotnie Schodnia, Biestrzynnik - pierwotnie Biestrzinnik). Jako przykład nazwy pierwotnie słowiańskiej, która ulegała później przemianom wskutek wpływów niemieckich, podano Krasiejów (pierwotnie Krascheow, a wcześniej również Crassiow). Przywołano też nazwy nawiązujące do okresu "najważniejszego” z punktu widzenia rozwoju gospodarczego regionu, czyli drugiej połowy XVIII w., nazwy, które wywodziły się od nazwisk „najwybitniejszych postaci” tamtego czasu, np. Grodziec (pierw. Friedrichgrätz lub Friedrichu Hradec - nazwany na cześć Fryderyka Wielkiego); Krzyżowa Dolina (pierw. Kreuzthal na cześć ministra von Kreuza); Mnichus (pierw. Münchhausen - ku czci ministra von Münchhausena); Antoniów (pierw. Colonia Antonia - na cześć pruskiego ministra Friedricha Antona von Heinza). Przypomniano przy okazji historyczną nazwę Ozimka - Malapane, nawiązującą do słowiańskiej nazwy rzeki Mała Panew. Podając te przykłady, wnioskodawcy chcieli uwypuklić historyczne znaczenie nazw gminy Ozimek, uważając, że

85 Wniosek o ponowne podjęcie czynności zmierzajacych do wprowadzenia podwójnego nazewnictwa miejscowości gminy Ozimek, 31 III 2016 r. Pismo wpłynęło do Rady 1 IV 2016 r. Zob.: www.ozimek.pl/static/Scan-petycji-RM12016.pdf (dostęp: 1 X 2016 r.). 
chociażby z tego względu należy zabiegać o ich przywrócenie w postaci podwójnego nazewnictwa: współczesnego i historycznego.

Zwracano ponadto uwagę, iż proces przygotowania lokalnej społeczności na wprowadzenie tych nazw winien być poprzedzony stosowną akcją uświadamiającą i promocyjną, aby „demagogiczne hasła” i „nieznajomość historii i lokalnych uwarunkowan” nie zdominowały dyskusji i nie wzięły górę nad „prawdą o tożsamości naszej małej ojczyzny", jak to miało miejsce na wcześniejszych spotkaniach. Podkreślano jednocześnie, że chodzi o ojczyznę wszystkich mieszkańców: Ślązaków, przybyszów i ich potomków. Zadeklarowano przy tym pomoc w tych działaniach. Uważano, że wprowadzenie podwójnych nazw miejscowości na terenie gminy może być doskonałym elementem jej promocji nie tylko w kraju, ale i za granica, tym bardziej że wpisuje się doskonale w „tworzącą się, piękną mozaikę Europy Regionów"86. Petycja została podpisana przez przewodniczącego Zarządu Gminnego TSKN na Śląsku Opolskim - Gminy Ozimek, Klausa Leschika. Argumenty przytoczone w piśmie świadczą najlepiej o tym, jak bardzo zależy przedstawicielom mniejszości w gminie Ozimek na przywróceniu „ich” nazw i z jaką determinacją walczą o nie; tym bardziej że w innych miejscowościach Opolszczyzny nazwy niemieckie już funkcjonują i są widoczne na tablicach drogowych.

Podobna sytuacja miała miejsce w Strzelcach Opolskich (gmina miejsko-wiejska, woj. opolskie), gdzie radni po raz kolejny w 2014 r. odrzucili wniosek z podpisami mniejszości narodowości niemieckiej dotyczący wprowadzenia polsko-niemieckich tablic z nazwami miejscowości; nie wyrażono nawet zgody (większością głosów) na konsultacje społeczne ${ }^{87}$. Wcześniej sprawa ta była wielokrotnie podnoszona przez mniejszość niemiecką (zwłaszcza w okresie wyborów samorządowych) i wciąż budziła wiele emocji wśród mieszkańców Strzelec Opolskich. Ostatecznie konsultacje w tej sprawie zostały przeprowadzone w maju 2015 r.; ich inicjatorem był burmistrz Strzelec Opolskich, Tadeusz Goc. W uzasadnieniu oświadczył, iż chciał poznać opinię mieszkańców, aby „raz na zawsze zakończyć ten temat”88. W konsultacjach wzięło udział ponad 8700 osób, czyli 34,98\% ogółu uprawnionych do głosowania. Na pytanie o to, „Czy jest Pan/Pani za wprowadzeniem dodatkowej nazwy miejscowości w języku niemieckim?”, w większości miejscowości gminy mieszkańcy wypowiedzieli się negatywnie, natomiast w trzech miejscowościach większość była „za” podwójnymi nazwami. Komentując wyniki głosowania, Zofia Habasz (sołtys gminy Jędryń, przedstawicielka mniejszości) przyznała z zadowoleniem, że Rada Miejska, wyrażając zgodę na postawienie dwujęzycznych tablic, uszanowała wolę większości ${ }^{89}$. W styczniu 2016 r. radni zadecydowali ostatecznie, iż gmina Strzelce Opolskie zostanie wpisana do Rejestru samorządów, na których terenie funkcjonują nazwy 
w języku mniejszości. I tak na 27 sołectw należących do gminy Strzelce Opolskie z wnioskiem do MSWiA o zgodę na wprowadzenie dwujęzycznych tablic wystąpiły 3 wsie: Rozmierz (Rosmierz), Jędrynie (Jendrin) oraz Warmątowice (Warmuntowitz) ${ }^{90}$. Ustawienie tablic w trzech miejscowościach na terenie gminy jest swoistym kompromisem, stwierdził burmistrz Goc. Wdrożenie całej procedury z tym związanej będzie trwało około roku.

\section{Postawy mieszkańców Opolszczyzny wobec podwójnych nazw}

Reakcje społeczne na samo uchwalenie Ustawy o mniejszościach narodowych i etnicznych były, zwłaszcza w środowiskach mniejszości, wręcz entuzjastyczne: „Wreszcie wielonarodowa Polska” („Endlich multinationales Polen”), oznajmiał na pierwszej stronie wielki tytuł w „Schlesisches Wochenblatt” (styczeń 2005 r.) tuż po przyjęciu ustawy przez Sejm. Uzupełniała go ilustracja przedstawiająca symboliczną mapę Polski, a na jej tle wiązkę tablic $\mathrm{z}$ dwujęzycznymi nazwami miejscowości wychodzącymi promieniście z centrum Opolszczyzny ${ }^{91}$. Zwolennicy ustawy (głównie przedstawiciele mniejszości) byli zadowoleni przede wszystkim z faktu, że po tylu latach zabiegów ustawa została wreszcie uchwalona. Uważali to za „przejaw normalności".

Zróżnicowany odbiór społeczny wprowadzania dwujęzycznych nazw miejscowości na obszarze Opolszczyzny wynikał przede wszystkim ze specyfiki tego regionu (w odróżnieniu od sytuacji Górnego i Dolnego Śląska) i skomplikowanych stosunków ludnościowych na tym obszarze po przyłączeniu tych ziem do Polski po II wojnie światowej. Aby zrozumieć reakcje lokalnej społeczności, jej obawy, nieufność czy też otwarcie manifestowany sprzeciw wobec wprowadzania dwujęzycznych nazw miejscowości, należy sięgnąć do prac znawcy tej problematyki Michała Lisa, który w swych badaniach wiele uwagi poświęcił problematyce Śląska (jego historii przed II wojną światową i po niej), a także sytuacji ludnościowej na Śląsku Opolskim po 1945 r. oraz sprawom mniejszości niemieckiej na tym terenie w okresie 1989-2014².

Oceniając rozbieżności postaw wobec stawiania tablic drogowych z podwójnymi nazwami na wjeździe do danej miejscowości, należy mieć na uwadze kontekst historyczno-polityczny i społeczny oraz wzajemne zaszłości i zależności stosunków ludnościowych na tych ziemiach po II wojnie światowej (doświadczenia okresu wojny i okupacji z jednej strony, jak też te z okresu panowania władzy komunistycznej i prowadzonej przez nią polityki narodowościowej z drugiej), co miało decydujący wpływ na niełatwe relacje między ludnością rodzimą i napływową po $1945 \mathrm{r}$.

90 Zob.: Trzy opolskie wsie dostanq niemieckie nazwy, 8 I 2016 r., http://www.strefaagro.nto.pl/artykul/ trzy-opolskie-wsie-dostana-niemieckie-nazwy (dostęp: 5 X 2016 r.).

91 Zob.: Endlich ein multinationales Polen. Minderheiten können in ihren Sprachen amtliche Angelegenheiten erledigen, „Schlesisches Wochenblatt”, z 14-20 I 2005 r., s. 1 i 4.

92 Zob. m.in.: M. Lis, Polska ludność rodzima na Ślq̨sku po II wojnie światowej (politycznospołeczne uwarunkowania integracji): próba syntezy, Opole 1991; idem, Ludność rodzima na Śląsku Opolskim...; idem, Górny Ślask. Zarys dziejów do I wojny światowej, Opole 1993; idem, Górny Ślask. Zarys dziejów do połowy XX wieku, Opole 2001; idem, Mniejszość niemiecka na Ślqsku Opolskim...; idem, Ślqsk Opolski w warunkach transformacji ustrojowej państwa od 1989 roku, Opole 2013. 
i rzutowało w niemałym stopniu również na ogląd rzeczywistości w okresie przemian transformacji ustrojowej w Polsce po 1989 r. Nie sposób omówić wszystkich argumentów „za” i „przeciw” stosowanych w dyskusjach (wypowiedziach, komentarzach) w związku z wprowadzaniem podwójnego nazewnictwa miejscowości na Opolszczyźnie, warto zasygnalizować jednak najbardziej znamienne opinie, świadczące o znaczących różnicach w odbiorze społecznym tego zjawiska.

Nie ulega wątpliwości, że podwójne nazwy na tablicach miejscowości (a także urzędach) stanowią widoczny znak w przestrzeni publicznej, że dany teren jest zamieszkany przez mniejszość; jest to świadectwo „pamięci i szacunku dla korzeni regionu i języka mniejszości”; służy też „podtrzymywaniu tożsamości mieszkańców jako widoczny w przestrzeni symbol ich obecności"93. Paweł Popieliński zwraca uwagę, że każda z generacji inaczej odbiera znaczenie podwójnego nazewnictwa w przestrzeni publicznej: dla ludzi w starszym wieku nazwy w języku niemieckim jest to kwestia „godności i naprawy krzywd z przeszłości”, dla średniego pokolenia to rodzaj podkreślenia podmiotowości i zaznaczenia, że „my tu jesteśmy”; dla ludzi młodych to "rodzaj refleksji historycznej” ${ }^{4}$.

Wprowadzanie dwujęzycznych nazw miejscowości budziło jednak (zwłaszcza na początku) wiele emocji społecznych. Reakcje były bardzo różne ${ }^{95}$. Część osób nie należących do mniejszości nie wyrażała zastrzeżeń co do możliwości wprowadzenia podwójnych nazw, twierdząc, że im to „nie przeszkadza”, a nawet są „zdecydowanie za". Nie brakowało też jednak reakcji zgoła odmiennych. Kogo bolq oczy od niemieckich nazw - pod tak znamiennym tytułem ukazał się w maju 2008 r. artykuł w tygodniku „Przegląd”, w którym Beata Dżon zebrała i przedstawiła różnorodne postawy mieszkańców Opolszczyzny wobec podwójnych nazw na tablicach drogowych w ich gminach ${ }^{96}$. Jak zauważyła, nie należy się jednak spodziewać szybkiego „wysypu” niemieckich nazw na Śląsku Opolskim; decyzje w tej sprawie są bowiem „delikatne i trudne”, samorządy są „ostrożne”, a i same procedury z tym związane trwają długo (przykładem może być wspomniana gmina Radłów). Autorka wspomniała też, że

94 Ibidem. Dla porównania można wspomnieć, że według badań pilotażowych przeprowadzonych w okresie od czerwca do listopada 2009 r. w Hajnówce i okolicy (wschodnie Podlasie) na temat dwujęzyczności osób pochodzenia białoruskiego na tym terenie 47,9\% młodych respondentów określających swą narodowość jako polską wyrażało zgodę, aby nazwa rodzinnego miasta (wsi, ulicy) była zapisana na tablicach wjazdowych do danej miejscowości (oraz na tablicach informacyjnych) zarówno w języku polskim, jak i białoruskim. Inicjatywy tej nie popierało 52,1\% młodych Polaków. Natomiast wśród młodzieży pochodzenia białoruskiego stopień akceptacji dla podwójnych tablic wynosił $100 \%$. W pokoleniu rodziców wśród osób uważających siebie za Polaków brak poparcia dla dwujęzycznych nazw rodzimej miejscowości (wsi) był wyższy i wynosił 70,8\%; w tej grupie wiekowej również 9,5\% Białorusinów nie popierało takiego rozwiązania. Natomiast tylko 29,2 \% osób określających swoją narodowość jako polską oraz 90,5\% badanych narodowości białoruskiej akceptowało dwujęzyczne nazwy na tablicach swej miejscowości; szerzej zob.: A.J. Siegień-Matyjewicz, Prawo do dwujęzyczności - zgoda czy konflikt? Raport z badań dotyczqcych dwujęzyczności osób pochodzenia białoruskiego zamieszkujących tereny Wschodniego Podlasia, „Pogranicze. Studia Społeczne”, t. XVII (2011), s. 238-242.

95 Zob.: reakcje mieszkańców na próby wprowadzania dwujęzycznych nazw miejscowości w okresie, zanim uchwalono Ustawę o mniejszościach narodowych i etnicznych, umożliwiającą ich ustawianie, m.in.: M. Wagińska-Marzec, Postawy mieszkańców Opolszczyzny..., s. 68. 
hotele, restauracje czy parafie, nie czekając na oficjalne decyzje polityczne władz, same wprowadzały napisy niemieckie na prywatnych obiektach czy zabytkach.

Przybliżając historyczno-społeczne tło tego regionu, autorka przytoczyła barwną mozaikę różnorodnych opinii wyrażanych przez osoby zarówno starszego, jak i młodego pokolenia, przedstawicieli mniejszości niemieckiej, Ślązaków, jak też ludności napływowej na temat stosunku do podwójnego nazewnictwa miejscowości na Opolszczyźnie. Ze względu na pewną przekrojowość postaw, a także dla zobrazowania skali akceptacji (bądź jej braku) dla dwujęzycznych nazw wśród mieszkańców regionu, warto przytoczyć kilka najbardziej charakterystycznych wypowiedzi i opinii na ten temat.

Okazuje się, że w połowie 2008 r. (a więc w zasadzie w początkowej fazie akcji wprowadzania podwójnego nazewnictwa miejscowości) chęć podkreślania niemieckiej przeszłości tych ziem nadal budziła lęk, niekiedy nawet w najbliższym otoczeniu sąsiadów, z którymi przedstawiciele mniejszości żyli w zgodzie od dziesiątek lat: „Póki niczego nie chcę, to jestem dobra sąsiadka, jak mówię o niemieckich tablicach czy pomnikach, to już jestem Niemka" - uważała starsza mieszkanka Chrząstowic ${ }^{97}$. Ludzie młodzi nie widzieli potrzeby przypominania historycznych nazw niemieckich; zapowiadali wręcz swoją negatywną reakcję w takiej sytuacji („Jestem przeciwny tabliczkom. Jeżeli tylko jakaś znajdzie się pod nazwą mojej miejscowości, to ja też zadziałam" - deklarował Damian z I klasy LO) ${ }^{98}$. Niektórzy mieszkańcy zwracali uwagę na brak konsultacji społecznych w tej sprawie („Ja tylko żałuję, że w Chrząstowicach nie było żadnej debaty. Zadałbym pani wójt kilka pytań. Ile tabliczek ma zostać umieszczonych? Ile kosztują? Czy stać na to gminę, bo na nowe chodniki nie? Nie lepiej za te pieniądze zrobić sygnalizację świetlną tam, gdzie mieszkańcy o to proszą od kilku lat? Uważam, że to kompromitacja narodu polskiego, sami sobie narzucamy obcojęzyczne nazwy"). Wszystkie te pytania świadczą ewidentnie o braku podstawowej wiedzy nie tylko na temat przeszłości tych ziem, ale też samego procesu wprowadzania podwójnego nazewnictwa na tym terenie oraz procedur $\mathrm{z}$ tym związanych. Być może wielu sporów i obaw społecznych można by uniknąć, gdyby proces wprowadzania podwójnych nazw został poprzedzony zawczasu szeroko zakrojoną debatą publiczną i odpowiednią akcją informacyjną, dzięki czemu mieszkańcy mieliby okazję dowiedzieć się chociażby tego, iż pieniądze na postawienie tablic drogowych będą pochodziły z puli ministerstwa, a nie z budżetu gminy, co budziło największy sprzeciw.

Zapytany o opinię na temat stosunku do podwójnych nazw abp prof. Alfons Nossol, niepodważalny autorytet dla mieszkańców, jak przyznawali zgodnie miejscowi Polacy i Niemcy, wskazywał na element wielokulturowości Opolszczyzny jako cenną wartość; podkreślał przy tym przenikanie się różnych tradycji: „Nasz region to pojednana 
różnorodność. Amalgamat tradycji śląskiej, Kresów Wschodnich i Polski centralnej"99. Podobnego argumentu użył też przedstawiciel młodego pokolenia mniejszości niemieckiej, przewodniczący rady gminy Chrząstowic, 30-letni Rafał Bartek, starając się przekonać mieszkańców, że „historia i ludzie różnych narodowości są bogactwem, tak było tu setki lat"100.

Sprawa podwójnego nazewnictwa była jednym z kluczowych punktów programu wyborczego mniejszości niemieckiej w gminie Strzeleczki (Klein Strehlitz), gdzie w spisie powszechnym z 2002 r. narodowość niemiecką zadeklarowało aż 41,6\% mieszkańców. Nie dziwi więc wynik głosowania radnych: za wprowadzeniem podwójnych nazw opowiedziało się 10 radnych, przeciwnych było 2, wstrzymało się od głosu 2 radnych. Podwójne nazwy wprowadzono w gminie już w listopadzie 2008 r. dla 19 wsi i przysiółków ${ }^{101}$. Koszty postawienia tablic z nazwami miejscowości pokrywał budżet państwa (ok. 39 tys. zł), natomiast środki na tablice urzędów pochodziły z budżetu gminy (ok. 5 tys. zł) ${ }^{102}$.

Niemal powszechną akceptację wprowadzenia niemieckich nazw miejscowości dało się zauważyć też w gminie Zębowice; radni już w 2006 r. podjęli uchwałę w tej sprawie, przy czym niemal wszyscy opowiedzieli się za wprowadzeniem podwójnych nazw wsi, w tym również ludność napływowa. Gabriela Buczek, szefowa lokalnego koła TSKN, przewodnicząca Rady Gminy, uważała, iż nazwy te będą „,wabikiem dla turystów”, którzy będą mogli zobaczyć, że jest to „ziemia wielokulturowa”103. Jednakże oficjalnie w gminie Zębowice nazwy niemieckie dla 10 wsi i przysiółka wprowadzono dopiero 19 listopada 2008 r.; nie wprowadzono natomiast dodatkowych nazw dla 5 części wsi oraz dwunastu przysiółków ${ }^{104}$.

Nie wszędzie jednak chciano manifestować wielokulturowość i sięgać do przeszłości. W powiecie Kędzierzyn-Koźle mniejszość niemiecka wprawdzie chciała podwójnych nazw, ale nie było w tej kwestii jednomyślności. Podobnie było w gminie Polska Cerekiew, gdzie część mieszkańców uważała, że jest to „hołd oddany historii”, "gest w stronę przybyszów z Zachodu”, a inni twierdzili (jak np. radny Włodzimierz Karliński), że nazwy niemieckie nie są potrzebne. Wiceprzewodniczący Rady Gminy, Jan Cieślak, zapowiedział wręcz, że wystąpi z rady, jeśli radni wyrażą zgodę na niemieckie nazwy. Zdania były bardzo podzielone; wciąż toczyły się na ten temat burzliwe dyskusje.

O dziwo ludzie młodzi byli - jak wynika z niektórych wypowiedzi - na ogół przeciwni niemieckim nazwom na tablicach (choć niekiedy manifestowano obojętny

100 Ibidem.

101 Zob.: Dwujęzyczne nazewnictwo geograficzne...

102 B. Dżon, op. cit.

103 Ibidem.

104 Zob.: Dwujęzyczne nazewnictwo geograficzne... 
stosunek do tej kwestii). Deklarowali, że nie interesuje ich historia, ale teraźniejszość: „Rozumiem, że to może być ważne dla starszego pokolenia, ale ja i moi znajomi nie sięgamy w przeszłość, nas interesuje dziś!" ${ }^{105}$. Niektórzy (np. licealiści z Opola) wyrażali swą opinię bardziej zdecydowanie: „To jest Polska, nie Niemcy, a wojna skończyła się 63 lata temu. Nie podoba nam się fakt, że mielibyśmy żyć w Oppeln". Inna młoda osoba mówiła: „Przypomina mi to germanizację z czasów II wojny. Jeżeli mnie kojarzy się w taki sposób, co mogą myśleć na ten temat osoby, które tamte wydarzenia przeżyły? Zapewne przywróci im to wspomnienia z tamtych lat" ${ }^{106}$. Z kolei jej matka była innego zdania; uważała, że dwujęzyczność to niezwykła cecha Opolszczyzny [w domyśle - którą warto by wyeksponować].

Niekiedy zwracano uwagę na fakt, że w gruncie rzeczy niewiele osób zna tak naprawdę język niemiecki i potrafi się nim posługiwać; władają nim jedynie ci, którzy pracują w Niemczech bądź studenci, a wcale nie zawsze ci, którzy wywodzą się z rodzin „z pochodzeniem”. Nauczycielka z Tarnowa Opolskiego przekonywała, że miejscowość powinna mieć nazwę obecną i mieszkańcy powinni się utożsamiać ze współczesnym Tarnowem, a nie z tym "historycznym”.

Przedstawiciele mniejszości niemieckiej reagowali na różne skrajne wypowiedzi na ogół ze spokojem. Maria Kwiecińska sugerowała, że najlepiej odczekać, aż emocje opadną: „To, co wyczekane ma szczególną wartość”, mówiła ${ }^{107}$. Odniosła się też do opinii niektórych mieszkańców Opolszczyzny, twierdzących, że „bolą ich oczy od niemieckich nazw”, chociaż przecież - jak skonstatowała - „jeszcze się na nie nie napatrzyli". Skomentowała też inne, bardziej drastyczne wypowiedzi, które wynikają, jej zdaniem, bądź to z niewiedzy, bądź też z niechęci do mniejszości, którą traktują „jak folklor”. Podkreśliła zarazem, że jest dumna z tego, że może ujawnić swoją niemiecką narodowość i mówić, kim się czuje.

Osobom spoza Opolszczyzny sprawa podwójnych nazw miejscowości była raczej obojętna, o czym świadczą niektóre z zebranych wypowiedzi („Nie przeszkadza mi to i nie obawiam się, może to i ciekawe. Jeśli ktoś mówi o germanizacji, to jakieś bzdury! Żyjemy w XXI w." - stwierdziła mieszkanka Poznania, bywająca często $u$ rodziny $w$ tym regionie).

Grzegorz Janusz, politolog z Uniwersytetu Marii Curie-Skłodowskiej z Lublina, specjalista w kwestii praw mniejszości narodowych i etnicznych, zwracał uwagę, że przywracanie tożsamości jest konieczne. Z jego obserwacji wynika jednak, że - jak pokazały przeprowadzone ostatnio spisy ludności w krajach europejskich - można dostrzec pewną tendencją spadkową, jeśli chodzi o liczbę osób deklarujących przynależność do mniejszości narodowych lub etnicznych. Beata Dżon zastanawia się więc, „Czy w tej sytuacji kwestia dwujęzycznych tablic to «wiele hałasu o nic»?”108.

105 Ibidem.

106 Ibidem

107 Ibidem.

108 Ibidem. 
Analizując różnorodne wypowiedzi na temat stosunku do podwójnych nazw na terenie Śląska Opolskiego, można stwierdzić, że z niektórych przebija spora doza lęków związanych z możliwością pojawienia się dwujęzycznych tablic miejscowości w ich regionie na większą skalę. Niekiedy był to wręcz jawnie i otwarcie artykułowany sprzeciw i brak akceptacji wprowadzania na tablice drogowe niemieckich nazw miejscowości. Obawiano się przede wszystkim, że będzie to nowy przejaw „germanizacji" tych terenów. Należy jednak zwrócić uwagę, że opinie te pochodziły z roku 2008, kiedy problem podwójnych nazw był jeszcze stosunkowo świeży i w gruncie rzeczy tablic z dwujęzycznymi nazwami miejscowości nie było zbyt wiele; można zatem przypuszczać, że były to trochę obawy „na wyrost”. Właśnie rok 2008 r. był poniekąd przełomowym, gdyż to wówczas na Opolszczyźnie najwięcej gmin (aż 13) uzyskało zgodę na wprowadzenie na swym terenie tablic drogowych z podwójnym nazewnictwem. Cztery lata później, w 2012 r. Łukasz Biły zauważył, iż dwujęzyczne tablice stały się już „stałym elementem krajobrazu Górnego Śląska”. W jego przekonaniu ich obecność świadczy o tym, że „Państwo Polskie wspiera i szanuje swoich obywateli narodowości innej niż polska". Uważał, że pokazują one całej lokalnej społeczności oraz gościom odwiedzającym ten region, że „podobnie jak na tablicy widnieje nazwa w języku mniejszości obok nazwy polskiej, tak samo zgodnie na danym terenie wspólnie żyją i pracują mieszkańcy różnej narodowości”109.

Wydaje się, że w miarę upływu czasu mieszkańcy Opolszczyzny mieli już okazję oswoić się z obecnością dwujęzycznych tablic na swym terenie i przestały one ich tak bardzo razić. Burmistrz Sośnicowic zauważył, że reakcje mieszkańców były do tej pory życzliwe, poza dwoma przypadkami; protest złożył jeden z historyków, zamieszkały w Gliwicach, który zarzucił władzom „sprzyjanie germanizacji polskich ziem i nawiązywanie do czasów II wojny światowej"110; doszło też do nielicznych incydentów zamalowania tablic ${ }^{111}$. Historia ma swoje znaczenie, dowodził burmistrz, i tego się nie zmieni. Odwołując się do faktu, iż chcemy być Europejczykami i należymy do Unii Europejskiej, przypomniał, że przecież w prawie europejskim i w polskich aktach prawnych istnieją odpowiednie przepisy, które te sprawy reguluja. Stąd też niezrozumiałe było dla niego owo „zacietrzewienie”. Uważał, że w tym wypadku „zadecydowała demokracja i nie powinno to nikogo denerwować” ${ }^{112}$. Publicysta „Dziennika Zachodniego” Dawid Smolorz tłumaczył, że wciąż mamy w naszym kraju do czynienia z „resentymentami antyniemieckimi”, co ma swe uzasadnienie historyczne i wynika z poczucia obecności „dużego sąsiada”, który kiedyś stanowił zagrożenie i dzisiaj potencjalnie też może być tak postrzegany ${ }^{113}$.

109 Ł. Biły, op. cit.

110 M. Szewczyk, op. cit.

111 Zob.: Dwujęzyczne nazwy miejscowości. Za czy przeciw?, 5 II 2014 r., http://wiadomosci.onet.pl/slask/ dwujezyczne-tablice-zamazane-chodzi-o-walke-miedzy-hanysami-a-gorolami/cv49q (dostęp: 5 X 2016 r.).

112 M. Szewczyk, op. cit.

113 Ibidem. 
Nie wszyscy jednak, nawet w miarę upływu czasu, byli skłonni pogodzić się faktem występowania polsko-niemieckich nazw na Opolszczyźnie. Dla uzupełnienia obrazu różnych postaw dotyczących stosunku mieszkańców regionu Śląska Opolskiego wobec podwójnego nazewnictwa warto przytoczyć kilka komentarzy internetowych z 2014 r. Mimo że nie są one w zasadzie (z uwagi na anonimowość) miarodajnym źródłem informacji, to jednak właśnie owa anonimowość pozwala piszącym na pewną swobodę i szczerość wyrażania opinii na ten temat. Poniżej kilka cytatów wpisów internetowych zamieszczonych pod artykułem poświęconym wprowadzeniu dwujęzycznych nazw w siedmiu sołectwach wokół Gliwic:

Jestem Polakiem z krwi i kości, ale podwójne polsko-niemieckie nazewnictwo miejscowości nie wzbudza moich zastrzeżeń. To przecież wynika ze standardów unijnych. Na Opolszczyźnie od dawna istnieją takie dwujęzyczne nazwy. Nie uważam Niemców za wrogów, znacznie bardziej obawiam się Rosjan, którzy są realnym zagrożeniem dla Polski i Polaków. Nie wiem, jak zareagowałbym, gdyby się okazało, że istnieje w Polsce rosyjska mniejszość narodowa, która też domaga się dwujęzycznych nazw - polskich i rosyjskich. Wtedy miałbym poważny dylemat... ${ }^{114}$

[Podpisano: Wnikliwy obserwator, 24.01.2014 r.]. Nota bene ten sam wpis ukazał się wytłuszczoną czcionką pół godziny później z podpisem „Siniak”, co świadczy o tym, że powielano te same wypowiedzi.

W podobnym tonie utrzymany był inny wpis: „No, widziałem je, niech będą te dwujęzyczne tablice. Mnie one nie przeszkadzają." [ja234, 24 stycznia 2014 r.]. $\mathrm{Z}$ aprobatą, a zarazem z nutą sarkazmu wyrażał swój stosunek do dwujęzycznych tablic kolejny internauta: „Gliwice, jak cały Śląsk, są historycznie bardziej Niemieckie niż Polskie więc o co chodzi? Grupce przyjezdnych zza Buga coś nie pasuje to żegnam..." [IIort, 24 stycznia 2014 r.].

Były też jednak wpisy świadczące o zdecydowanie negatywnym stosunku do podwójnych nazw, np. „Bardzo proszę redakcję o sprawdzenie czy w Niemczech istnieją miejscowości oznaczone tablicami po polsku i po niemiecku??? Oraz ile kasy poszło w błoto na te tablice??? Żyjemy w Polsce mówimy po polsku i nazwy mają być po polsku!!!!" [Pablo, 24 stycznia 2014 r.]. Poniżej widniała odpowiedź internauty podpisanego [Bumerang]: „Sam sobie sprawdź. Wiem, że w okolicy Budziszyna (sam sobie sprawdź gdzie to miasto i jak się w Niemczech zowie) są tablice w języku niemieckim i łużyckim. I tak (fon.) Szwarce Pumpe po polsku Czarna Pompa po łużycku Cyrna Pumpa" [Boomerang, 24 stycznia 2014 r.]. Zdarzały się też komentarze podkreślające wysoki stopień oburzenia: „To jest chyba żart! Przedwczesne prima aprilis!" [Podpisano: Jestem z Polski!, 24 stycznia 2014 r.].

Niezależnie od opinii artykułowanych na łamach prasy (głównie lokalnej) bądź drogą internetową (zwłaszcza na stronie „nieTablicom.pl”), która umożliwiała wyrażanie sprzeciwu wobec pojawiania się niemieckich nazw miejscowości w przestrzeni 
publicznej na Opolszczyźnie, zdarzały się też inne formy protestu przeciwko temu zjawisku. Proceder niszczenia bądź zamalowywania tablic przedstawiła szerzej Monika Choroś, pokazując reakcje miejscowej ludności na stawianie dwujęzycznych tablic drogowych na tym terenie ${ }^{115}$. Z jej badań wynika, że trudno dokładnie ocenić, jaka była skala tego rodzaju aktów wandalizmu. $\mathrm{Z}$ opisanych przez autorkę sytuacji wynika też, iż przypadki takie miały miejsce raczej w początkowej fazie stawiania tablic z podwójnymi nazwami miejscowości. Obecnie tablice te są rzadziej niszczone, aczkolwiek „dwujęzyczne nazewnictwo nadal budzi emocje i wciąż występują przykłady braku jego akceptacji” i to zarówno wśród miejscowej ludności, jak i przedstawicieli władz ${ }^{116}$.

Potwierdzają to badania na temat stosunku Polaków do mniejszości narodowych i etnicznych, ich praw, wielokulturowości i współistnienia w jednym społeczeństwie przedstawicieli różnych kultur, przeprowadzone przez CBOS w 2015 r., po dziesięciu latach funkcjonowania Ustawy o mniejszościach narodowych i etnicznych oraz o języku regionalnym, które wskazują, że postawy te uległy w ciągu tych lat nieznacznym zmianom; widać, iż generalnie wzrosła jednak akceptacja różnorodności kulturowej.

Jeśli chodzi o stosunek do praw mniejszości, to większość ankietowanych w 2015 r. (79\%) uważała, że członkowie mniejszości narodowych i etnicznych powinni mieć możliwość nauki swego języka $\mathrm{w}$ polskich szkołach na dodatkowych lekcjach (w 2005 r. - 82\%); nieco wzrosła liczba osób, które uważały, że powinni oni mieć możność uczenia się w swoim języku (63\%; w 2005 r. - 61\%); nieco mniej niż połowa (43\%) uważała, że osoby te powinny otrzymać pomoc finansową od państwa na podtrzymywanie własnej kultury i tradycji (w 2005 r. - 41\%); mniej więcej tyle samo osób badanych było zdania, że powinni mieć możliwość posługiwania się swoim językiem w urzędach lokalnych w miejscowościach ich zamieszkania (41\%, w 2005 r. - 37\%).

Większy opór społeczny budziły jednak nadal sprawy dotyczące sfery publicznej; jedynie co trzeci ankietowany (32\%) uznał, że członkowie mniejszości narodowych i etnicznych powinni mieć możliwość zamieszczania tablic z nazwami miejscowości w swoim języku obok tablic z nazwami w języku polskim (w 2005 r. - 26\%); oznacza to, że stopień akceptacji podwójnych nazw nieco się podniósł. Mniej więcej na tym samym poziomie utrzymał się procent tych, którzy uważali, że członkowie tych mniejszości powinni być zwolnieni z wymogu przekroczenia progu 5\% głosów w skali kraju, aby wejść do Sejmu ${ }^{117}$. Wyniki te świadczą o tym, że wprawdzie nastawienie wobec przestrzegania praw mniejszości zagwarantowanych w Ustawie o mniejszościach narodowych i etnicznych nieznacznie się poprawiło, ale manifestowanie ich obecności w sferze publicznej nadal nie jest zbyt mile widziane.

115 M. Choroś, Wprowadzanie podwójnych nazw miejscowości w województwie opolskim, „Rocznik Ziem Zachodnich", R. 1 (2017)

116 Ibidem, s. 378-379.

117 Zob.: Tożsamość narodowa i postrzeganie praw mniejszości..., s. 4-5 (zwłaszcza tabele na s. 5 i s. 13). 
Wyraźnie widać, że początkowo, w pierwszych latach po wprowadzaniu podwójnego nazewnictwa na terenie opolskich wsi, budziły one - co zrozumiałe - mieszane uczucia wśród części miejscowej społeczności; czasami nie potrafiono zaakceptować tego faktu. Nawet jeszcze obecnie są dostrzegalne „akty wandalizmu i nietolerancji" w postaci zamalowywania sprayem (bądź w inny sposób) niemieckich nazw na tablicach wjazdowych; jest to bowiem odbierane jako wyraz podkreślania niemieckości tego regionu. Mimo że są to w większości nazwy o rodowodzie słowiańskim, wzbudzają wciąż jeszcze negatywne emocje. Zamalowywanie nazw niemieckich interpretowane jest jako rodzaj manifestowania braku ich akceptacji. Są to jednak, według Popielińskiego, przypadki coraz rzadsze ${ }^{118}$.

\section{Wokół projektu nowelizacji ustawy o mniejszościach}

$\mathrm{Z}$ uwagi na pewne propozycje zmian dotyczące m.in. również ustalenia dodatkowych nazw w języku mniejszości oraz trybu postępowania w tym przypadku, warto wspomnieć o projekcie nowelizacji Ustawy o mniejszościach narodowych i etnicznych oraz o języku regionalnym, którą zapowiedzieli posłowie sejmowej komisji mniejszości narodowych i etnicznych na początku $2015 \mathrm{r}$.

Uroczyste posiedzenie sejmowej komisji odbyło się w połowie lutego 2015 r., w 10. rocznicę uchwalenia ustawy. Przewodniczący Miron Sycz (PO) przypomniał, że była to jedna z najdłużej procedowanych ustaw w parlamencie; prace nad nią toczyły się w okresie 1989-2005. W ustawie po raz pierwszy uregulowano całościowo prawa obywateli polskich należących do mniejszości ${ }^{119}$. Eugeniusz Czykwin (SLD), ówczesny sprawozdawca, przypomniał, że w Sejmie długo nie było zgody na jej uchwalenie, gdyż obawiano się, że może ona naruszyć suwerenność Polski. Po latach jej funkcjonowania okazało się jednak, że - jak twierdził - została bardzo dobrze oceniona i jest obecnie „wzorcowym przykładem implementacji norm międzynarodowych w zakresie praw mniejszości" ${ }^{120}$. Poseł mniejszości, Ryszard Galla, zauważył, że ustawa nie była dotąd nowelizowana, toteż obecnie przygotowuje się projekt doprecyzowania niektórych jej zapisów (chodzi m.in. również o zmiany dotyczące funkcjonowania Komisji Wspólnej Rządu i Mniejszości Narodowych i Etnicznych, wyboru jej przedstawicieli, kadencyjności, etc.). Oceniając prace Komisji wiceszef Ministerstwa Administracji i Cyfryzacji i zarazem współprzewodniczący wymienionej Komisji Stanisław Huskowski, podkreślił, że jest ona bardzo potrzebnym organem, który sprawdził się w trakcie swej dziesięcioletniej działalności ${ }^{121}$.

118 P. Popieliński, op. cit., s. 224.

119 Zob.: Komisja: będzie nowela ustawy o mniejszościach narodowych i etnicznych, 19 II 2015 r., http:// wyborcza.pl/1,91446,17442591,Komisja__bedzie_nowela_ustawy_o_mniejszosciach_narodowych.html?disableRedirects=true (dostęp: 10 X 2016 r.).

120 Ibidem.

121 Komisja jest organem opiniodawczo-doradczym premiera w sprawach odnoszących się do mniejszości; jej postanowienia są wypracowywane na drodze porozumienia stron, a nie głosowania. Komisja zajmuje się opiniowaniem różnego rodzaju programów i projektów dotyczących mniejszości (większość dotyczy kwestii oświatowych); na wspieranie tożsamości kulturowej mniejszości komisja dysponuje funduszem w wysokości ok. 15,6 mln zł (2015), tj. o 600 tys. zł więcej niż w roku 2014. Zob.: Komisja: będzie nowela ustawy.. 
Danuta Pietraszewska (PO) podała jednocześnie do wiadomości, że podjęto prace nad projektem, który przewiduje m.in. uznanie śląskiego za język regionalny. $\mathrm{W}$ przekonaniu posłanki spełnią się dzięki temu oczekiwania kilkuset tysięcy obywateli polskich ${ }^{122}$. Nawiązując do jej wypowiedzi, poseł Marek Ast (PiS) zaznaczył, iż ze strony jego ugrupowania nie ma zgody na to, by język śląski uznać za regionalny. Wyraził jednocześnie opinię, że ustawa o mniejszościach narodowych i etnicznych świadczy najlepiej o tym, iż w Polsce respektuje się prawa mniejszości. Zwrócił przy tym uwagę, że w Europie nie ma symetrii, jeśli chodzi o traktowanie mniejszości polskiej poza granicami państwa ${ }^{123}$.

Poselski projekt nowelizacji ustawy o mniejszościach narodowych i etnicznych oraz o języku regionalnym wpłynął do Sejmu 10 czerwca 2015 r. ${ }^{124} \mathrm{Na}$ marginesie warto wspomnieć, że jedną z ważniejszych zmian, jakie przewidywał, było m.in. rozszerzenie na powiaty możliwości posługiwania się językami mniejszości narodowych i etnicznych oraz językiem regionalnym, jako językami pomocniczymi. Uprzednio językiem pomocniczym można się było posługiwać jedynie w kontaktach z organami gminy. Zmiana miała umożliwić organom nie tylko gminy, ale i powiatu stosowanie dwujęzycznych dokumentów w kontaktach z mniejszościami oraz zwracanie się do organizacji mniejszości narodowych i etnicznych z pismami dwujęzycznymi.

Prezydent Andrzej Duda nie podpisał jednak projektu nowelizacji ustawy, jak poinformowała Kancelaria Prezydenta 27 października 2015 r. Środowiska mniejszości przyjęły ten fakt z dużym zaniepokojeniem ${ }^{125}$. Wątpliwości prezydenta wzbudził właśnie zapis rozszerzający możliwości używania języka mniejszości jako języka pomocniczego przed organami powiatowymi ${ }^{126}$. Powodem zawetowania projektu przez Prezydenta był przede wszystkim brak należytego oszacowania kosztów finansowych dla budżetów powiatów i gmin, wynikających z tego tytułu. Należy dodać, że w projekcie noweli oceniono, że realizacja owego rozszerzenia spowoduje

122 Ibidem

123 Ibidem.

124 Harmonogram prac nad nowelizacją ustawy zob.: Poselski projekt ustawy o zmianie ustawy o mniejszościach narodowych i etnicznych oraz o jezyku regionalnym, a także niektórych innych ustaw, Druk nr 3545, Warszawa, 10 VI 2015 r., http://www.sejm.gov.pl/sejm7.nsf/PrzebiegProc.xsp?nr=3545 (dostęp: 12 X 2016 r.).

125 Zob.: Prezydent Andrzej Duda zawetował ustawęo mniejszościach narodowych i etnicznych, 27 X 2015 r., http://fakty.interia.pl/polska/news-prezydent-andrzej-duda-zawetowal-ustawe-o-mniejszosciach -nar,nId,1910782 (dostęp: 11 X 2016 r.). Zob. też: P. Guzik, Prezydent Duda przeciwny językowi mniejszości w urzędach. Niemcy i Kaszubi: Absurd, 28 X 2015 r., http://wyborcza.pl/1,75398,19099196,prezydent-duda-przeciwny-jezykowi-mniejszosci-w-urzedach-niemcy.html (dostęp: 14 X 2016 r.).

126 Język pomocniczy mógłby być używany jedynie w gminach i powiatach ujętych w Urzędowym Rejestrze Gmin i Powiatów. W noweli zaznaczono, że minister ds. wyznań religijnych oraz mniejszości narodowych i etnicznych może odmówić wpisu do Rejestru, jeśli liczba mieszkańców gminy lub powiatu, zamieszkiwanych przez mniejszość, której język ma być używany jako pomocniczy, jest mniejsza niż $20 \%$ ogółu mieszkańców danej gminy lub powiatu. Szerzej na temat innych zmian, jakie wprowadzała nowela ustawy, zob.: Prezydent Andrzej Duda zawetował... Por.: Sejm: Nowelizacja ustawy o mniejszościach narodowych. Zyskaja Ślqzacy, „Gazeta Prawna.pl”, 7 XII 2015 r., http://prawo.gazetaprawna.pl/artykuly/909603,sejm-mniejszosci-narodowe-slask.html (dostęp: 17 IV 2018 r.). 
wzrost wydatków o 10 tys. zł rocznie dla budżetu jednostki terytorialnej. Tak niskie oszacowanie związanych z tym kosztów wzbudziło właśnie „poważne wątpliwości” Prezydenta, jak podano w uzasadnieniu decyzji odmownej ${ }^{127}$.

Należy zaznaczyć, iż projekt nowelizacji przewidywał też istotną zmianę dotyczącą wprowadzania podwójnego nazewnictwa miejscowości. Uwzględniono w nim zapis, że na wniosek mniejszości Rada Gminy mogłaby podjąć (w formie uchwały) decyzję o ustaleniu dodatkowej nazwy miejscowości lub obiektu fizjograficznego w języku mniejszości. Dzięki takiemu rozstrzygnięciu w przypadku odrzucenia wniosku o ustalenie dodatkowej nazwy przysługiwałaby możliwość odwołania się od uchwały Rady Gminy. Obecnie, gdy wniosek zostanie odrzucony bez podjęcia uchwały, nie ma możliwości odwołania się od decyzji Rady Gminy ${ }^{128}$. Zmiana ta ma duże znaczenie dla dalszych działań mniejszości związanych z wprowadzaniem na swym terenie podwójnego nazewnictwa. Nowela przewidywała też, iż jeśli Prezydent odmawia podpisania ustawy, wówczas kieruje ją do Sejmu do ponownego rozpatrzenia' ${ }^{129}$.

Środowiska mniejszości odebrały weto Prezydenta jako „negatywny sygnał” wysłany pod swoim adresem ${ }^{130}$. Przedstawiciele mniejszości zwracali uwagę, że język jest dla nich „ważnym elementem tożsamości narodowej”"131. Rafał Bartek, współprzewodniczący Komisji, stwierdził, iż jest to „zastanawiające i niepokojące”, ponieważ zawetowana nowelizacja nie wprowadza w gruncie rzeczy żadnych dużych zmian w obowiązującej ustawie o mniejszościach, a jedynie reguluje „kwestie techniczne”, jak określił. Jeśli więc tak „drobne” zmiany zostały zawetowane, to należy uznać ten fakt za „niepokojący sygnał”, świadczący generalnie o podejściu Prezydenta do polityki mniejszościowej ${ }^{132}$. Poseł zwracał jednocześnie uwagę, że zmiana o wprowadzeniu

127 Zob.: Prezydent Andrzej Duda zawetował ustawę...

128 Zob.: Uzasadnienie poselskiego projektu ustawy, Druk nr 3545, Warszawa, 10 VI 2015 r., http://www. sejm.gov.pl/sejm7.nsf/PrzebiegProc.xsp?nr=3545 (dostęp: 9 X 2016 r.). Por.: Prezydent Andrzej Duda zawetowat trzy ustawy, 27 X 2015 r., http://prawo.gazetaprawna.pl/artykuly/901816,prezydent-andrzej-dudazawetowal-trzy-ustawy.html; por.: Prezydent Andrzej Duda zawetował trzy ustawy odchodzqcego Sejmu. Podpisał 22, 27 X 2015, https://www.polskieradio.pl/5/3/Artykul/1536925,Prezydent-Andrzej-Duda-zawe towal-trzy-ustawy-odchodzacego-Sejmu-Podpisal-22 (dostęp: 5 IV 2018 r.).

129 Sejm może odrzucić weto Prezydenta większością 3/5 głosów w obecności co najmniej połowy ustawowej liczby posłów. Jeśli w związku z upływem kadencji Sejm nie zajmie się wetem Prezydenta, wówczas zawetowana ustawa nie wchodzi w życie i podlega zasadzie dyskontynuacji (podobnie jak projekty ustaw).

130 Negatywnie decyzję Prezydenta odebrali również przedstawiciele mniejszości litewskiej. Przedstawiciel Komisji Wspólnej Rządu i Mniejszości Narodowych i Etnicznych i prezes Stowarzyszenia Litwinów w Polsce Algirdas Vaicekauskas podkreślił, iż „najważniejszym elementem tożsamości narodowej mniejszości jest język i ochrona tego języka", a najskuteczniejszym sposobem jego ochrony jest możliwość jego używania. Zaskoczony wetem Prezydenta był również poseł Eugeniusz Czykwin, reprezentujacy środowiska białoruskie i prawosławne. W jego odczuciu decyzja Prezydenta „budzi nieufność i niepokój”. Argument podany w uzasadnieniu odmowy, dotyczący ewentualnych kosztów realizacji nowelizacji ustawy, uznał za niezasadny, gdyż np. w gminach powiatu hajnowskiego w Podlaskiem, zamieszkiwanych przez mniejszość białoruską, nie skorzystano dotąd z możliwości wprowadzenia dwujęzycznych nazw miejscowości. Obecnie w Podlaskiem dwujęzyczne nazwy miejscowości funkcjonują w gminie Orla w powiecie bielskim (polsko-białoruskie) oraz w gminie Puńsk na Suwalszczyźnie (polsko-litewskie) W obu gminach doszło do zniszczenia tablic przez „nieznanych sprawców”. W przekonaniu Czykwina koszty finansowe nowelizacji są trudne formalnie do oszacowania, ale raczej byłyby „minimalne” i nieistotne w skali kraju. Zob.: Andrzej Duda zawetował trzy ustawy...

131 Ibidem. 
języka pomocniczego na szczeblu powiatów dotyczyłaby praktycznie jedynie czterech powiatów na terenie całego kraju: dwóch zamieszkiwanych przez Kaszubów oraz po jednym, w którym mieszka mniejszość białoruska i litewska ${ }^{133}$. Jeśli chodzi o wydatki samorządów z tym związane, to koszty te są, jego zdaniem, wręcz „symboliczne i żaden z samorządów nie poczułby problemu"134. Zawetowanie tej części ustawy uznał zatem albo za pewne „niedopatrzenie”, albo bardzo wyraźną oznakę tego, że nowelizacja nie może być przyjęta ${ }^{135}$.

Podobnie odebrał weto Prezydenta Miron Sycz, przewodniczący Komisji Mniejszości Narodowych i Etnicznych w minionej kadencji Sejmu, uznając, że to „dosyć zły sygnał" dla mniejszości narodowych. Obawiają się one, że będzie im trudniej funkcjonować w nowej rzeczywistości politycznej. Już w trakcie prac nad nowelizacją ustawy politycy PiS opowiadali się przeciwko jej zapisom ${ }^{136}$. Rozszerzenie możliwości posługiwania się językiem mniejszości na powiaty mogło być, zdaniem Sycza, wzorem tworzenia prawa dla krajów, w których zamieszkuje polska mniejszość narodowa. Przyznał, że w ten sposób chciano pokazać państwom sąsiadującym, że traktujemy mniejszości „w sposób godny”, co mogło stanowić dobry przykład do naśladowania ${ }^{137}$.

$\mathrm{Z}$ apelem do posłów PiS-u o odrzucenie weta Prezydenta dotyczące nowelizacji ustawy o mniejszościach narodowych i etnicznych zwrócił się poseł Andrzej Halicki (PO) na konferencji prasowej w MAC (29 października 2015 r.), argumentując, że nowelizacja „wychodzi naprzeciw oczekiwaniom nielicznych w Polsce mniejszości” w bardzo niewielkim zakresie. Chodzi o uzupełnienie dotychczasowych mechanizmów o możliwość używania własnego języka jako pomocniczego w urzędach gminnych i powiatowych, przy czym nowelizacja będzie dotyczyła de facto jedynie czterech powiatów ${ }^{138}$. Jakie będą dalsze losy nowelizacji, trudno na razie przewidzieć; widać jednak ewidentnie, jak wiele emocji społecznych i politycznych wzbudzają nadal kwestie dotyczące bezpośrednio spraw mniejszości narodowych i etnicznych.

133 Zob.: Prezydent zawetował nowelę ustawy o mniejszościach narodowych. „Źle się stało”, 27 X 2015 r., http://www.tvn24.pl/wiadomosci-z-kraju,3/ustawa-o-mniejszosciach-narodowych-i-etnicznych-wetoprezydenta,589513.html (dostęp: 14 X 2016 r.).

134 Zob.: Zawetowana ustawa o mniejszościach wróci do Sejmu?, 28 X 2015 r., http://www.polskieradio pl/7/1691/Artykul/1537512,Zawetowana-ustawa-o-mniejszosciach-wroci-do-Sejmu (dostęp: 14 X 2016 r.).

135 Zob.: Prezydent Andrzej Duda zawetował trzy ustawy...

136 Ibidem

137 Zob.: Prezydent zawetował nowelę ustawy...

138 Zob.: Halicki do PiS: odrzućcie weto prezydenta ws. ustawy o mniejszościach narodowych i etnicznych, 29 X 2015 r., http://wiadomosci.wp.pl/kat,1342,title,Halicki-do-PiS-odrzuccie-weto-prezydenta-wsustawy-o-mniejszosciach-narodowych-i-etnicznych,wid,17941975,wiadomosc.html?ticaid=117f86\&_ticrsn=3 (dostęp: 15 X 2016 r.). 


\section{Zakończenie}

Próbując odpowiedzieć na pytanie, jak z perspektywy dzisiejszej ocenić realizację zapisów ustawy w zakresie wprowadzania dwujęzycznego nazewnictwa, warto przytoczyć kilka liczb, które dają najlepszy obraz rozmiarów tego zjawiska: ogółem w okresie 2006-2016 zostały ustalone dodatkowe nazwy w języku mniejszości narodowej i etnicznej w 58 gminach dla: 1240 miejscowości oraz ich części (w tym: 14 miast, 783 wsi, 180 części wsi, 45 przysiółków, 134 osad, 33 osad leśnych/leśniczówek, 44 kolonii i 7 części kolonii i osad), w tym: 359 nazw niemieckich (Śląsk), 815 nazw kaszubskich (Pomorze), 30 nazw litewskich, 27 nazw białoruskich oraz 9 nazw łemkowskich ${ }^{139}$; $\mathrm{z}$ tego $\mathrm{w}$ województwie opolskim dodatkowe nazwy niemieckie wprowadzono na terenie 28 gmin, a w województwie śląskim $3 \mathrm{gmin}^{140}$. W żadnej z gmin nie ustalono dodatkowych nazw dla wszystkich miejscowości; nie ustalono też żadnej nazwy dodatkowej dla obiektu fizjograficznego ani też nazw ulic czy placów; nazwy takie funkcjonują jedynie sporadycznie w niektórych miejscowościach. Wyniki te świadczą najlepiej o tym, że proces wprowadzania podwójnych nazw miejscowości na terenach zamieszkanych przez mniejszości narodowe i etniczne jest systematycznie realizowany. Należy zauważyć, że najwięcej dodatkowych nazw wprowadzono na Kaszubach, drugie miejsce w kolejności zajmują nazwy dwujęzyczne na Śląsku Opolskim.

Oceniając przebieg wprowadzania dodatkowych nazw niemieckich, można stwierdzić, że funkcjonują one już na terenie 31 gmin województwa opolskiego i 3 śląskiego. Najwcześniej tablice z podwójnymi nazwami postawiono w gminie Radłów (2006 r.) oraz Cisek (2007 r.); z kolei najwięcej tablic powstało w roku 2008, bo aż w 13 gminach (Leśnica, Rudnik w woj. śląskim, Tarnów Opolski, Chrząstowice, Izbicko, Dobrodzień Jemielnica, Kolonowskie, Krzanowice w woj. śląskim, Ujazd, Zębowice, Biała, Strzeleczki); w kolejnych latach przybywało ich w znacznie mniejszym wymiarze: 2009 r. - w 5 gminach (Murów, Walce, Głogówek, Komprachcice, Dobrzeń Wielki); 2010 r. - w 4 gminach (Łubniany, Prószków, Gogolin, Lasowice Wielkie); 2011 r. - w 3 gminach (Bierawa, Reńska Wieś, Polska Cerekiew); 2012 r. - w 1 gminie (Turawa) ${ }^{141}$; 2013 r. - w 1 gminie (Sośnicowice, woj. śląskie) ${ }^{142} ; 2014$ r. - w 2 gminach (Popielów, Pawłowiczki). Wkrótce do tego zestawienia dołączy kolejna gmina, gdyż na zgodę na postawienie tablic oczekują jeszcze 3 sołectwa w gminie Strzelce Opolskie (Jędrynie, Rozmierz i Warmątowice) ${ }^{143}$.

139 Zob.: Dwujęzyczne nazewnictwo geograficzne w Polsce (stan z 18 VII 2016 r.),

https://pl.wikipedia.org/wiki/Dwuj\%C4\%99zyczne_nazewnictwo_geograficzne_w_Polsce (dostęp: 5 XI 2017 r.),

140 Zob.: Lista gmin wpisanych do Rejestru gmin, na których obszarze używane sq nazwy w języku mniejszości, http://mniejszosci.narodowe.mswia.gov.pl/mne/rejestry/rejestr-gmin/6794,Rejestr-gmin-na-kto rych-obszarze-sa-uzywane-nazwy-w-jezyku-mniejszosci.html (dostęp 24 X 2017 r.).

141 W gminie Turawa wprowadzono 11 nazw niemieckich dla wsi w 2012 r. oraz 1 dla przysiółka (Trzęsiona - Trzenschin) w 2013 r.

142 W gminie Sośnicowice wprowadzono 6 niemieckich nazw dla miasta i wsi w 2013 r. oraz 1 dla wsi w 2014 r.

143 P. Popieliński przytacza dane dotyczące liczby wprowadzenia podwójnych nazw w języku niemieckim w województwie opolskim i śląskim w poszczególnych latach, np. w 2009 r. - w 21 gminach 197 nazw niemieckich; 2012 r. - w 26 gminach woj. opolskiego 229 nazw i w 2 gminach woj. ślaskiego 6 nazw 2013 r. - 320 nazw; 2014 r. - w 26 gminach woj. opolskiego 330 nazw i w 3 gminach woj. śląskiego 12 nazw; zob.: P. Popieliński, op. cit., s. 220. 
Obraz ogólnej liczby dwujęzycznych nazw na Śląsku Opolskim może jednak ulec wkrótce pewnym modyfikacjom w związku z tym, że miasto Opole powiększyło swój obszar od 1 stycznia 2017 r. o tereny kilku ościennych sołectw ${ }^{144}$. Mieszkająca w nich mniejszość niemiecka obawiała się w związku z tym, że utraci przez to część przywilejów wynikających z ustawy o mniejszościach (w tym także prawo do dwujęzycznych tablic z nazwami miejscowości), gdyż nie spełni podstawowego wymogu $20 \%$ ogółu mieszkańców, by być uznaną za mniejszośćc ${ }^{145}$. Ówczesny wicemarszałek województwa, Roman Kolek (z mniejszości niemieckiej), podkreślał, że powiększenie Opola jest forsowane „bez poszanowania wyraźnego sprzeciwu mieszkańców sąsiednich gmin wyrażonego w konsultacjach społecznych"146.

Obserwując przebieg procesu wprowadzania podwójnych nazw, należy stwierdzić, że towarzyszące temu emocje społeczne były obecne przede wszystkim w pierwszej fazie stawiania dwujęzycznych tablic, kiedy jeszcze nie do końca było wiadomo, jak to faktycznie będzie wyglądało $\mathrm{w}$ praktyce i jaka będzie skala tego zjawiska. Społeczność lokalna była więc pełna obaw i lęków, podsycanych umiejętnie przez niektórych działaczy prawicowych, którzy ostrzegali przed „ostrą manifestacją niemieckości" na tym terenie. Niemałą rolę w takim właśnie naświetleniu problemu odegrała też lokalna prasa, uwypuklając zwłaszcza elementy drażliwe i kontrowersyjne. Wydaje się jednak, że w miarę upływu czasu poziom akceptacji mieszkańców Opolszczyzny dla podwójnych nazw w ich regionie znacznie wzrósł, a głosów sprzeciwu i sygnalizowanych obaw z tym związanych jest coraz mniej, podobnie jak przypadków niszczenia tablic, co nie znaczy, że w ogóle do tego nie dochodzi. Zdania na ten temat nadal są podzielone, co potwierdzają również wyniki badań. Być może podwójne nazwy „wrosły” już na tyle w krajobraz Opolszczyzny i tak dalece się $\mathrm{w}$ nim zadomowiły, że $\mathrm{w}$ jakimś stopniu oswojono się $\mathrm{z}$ ich obecnością i dwujęzyczne nazwy miejscowości przestały tak bardzo razić. Obawy, jakie zgłaszano na początku, że będzie to powtórna "germanizacja” tych terenów, nie sprawdziły się. Pozytywną rolę odegrał też, być może, przykład innych wielokulturowych obszarów w różnych krajach europejskich, gdzie dwujęzyczne nazwy miejscowości są na porządku dziennym i nikogo nie dziwią, o czym można się przekonać, podróżując swobodnie po Europie.

144 Projekt powiększenia Opola przewidywał włączenie do miasta 4 gmin: gmina Dąbrowa miała utracić miejscowości: Sławice, Wrzostki i cześć Karczowa; gmina Dobrzeń Wielki - sołectwa: Borki, Czarnowąsy, Krzanowice, Świerkle oraz część Brzezia i Dobrzenia Wielkiego; gmina Komprachcice - sołectwa: Chmielowice i Żerkowice; gmina Prószków - Winowo.

145 A. Pawlak, Wielkie Opole nie po niemiecku. Zniknq dwujęzyczne tablice z nazwami miejscowości, „Gazeta Wyborcza", z 5 VIII 2016 r.

146 P. Guzik, M. Łodziński, Większe Opole. Rzqd zatwierdzi poszerzenie granic miasta w 2017 roku! 19 VII 2016 r., http://opole.wyborcza.pl/opole/1,35086,20423849,wieksze-opole-rzad-zatwierdzil-poszerzenie-granic-miasta.html (dostęp: 25 X 2016 r.). 


\section{Bibliografia}

Berlińska D., Mniejszość niemiecka na Ślqssku Opolskim w poszukiwaniu tożsamości, Opole 1999.

Berlińska D., Niemieckie dziedzictwo kulturowe jako element rekonstrukcji tożsamości mniejszości niemieckiej na Śląsku Opolskim, [w:] Wspólne dziedzictwo? Ze studiów nad stosunkiem do spuścizny kulturowej na Ziemiach Zachodnich i Północnych, red. Z. Mazur, Poznań 2000, s. 553-584.

Berlińska D., Postawy młodzieży licealnej wobec niemieckiej przeszłości i "malej ojczyzny” na Ślq̨sku Opolskim, „Zeszyty Instytutu Zachodniego”, nr 1 (1998), s. 1-24.

Berlińska D., Sołdra-Gwiżdż T., Ludność rodzima i mniejszość niemiecka w Polsce, [w:] Polskie badania nad mniejszościami kulturowymi. Wybrane zagadnienia, „Pogranicze. Studia Społeczne”, t. VI (1997), s. 73-103.

Choroś M., Dwujęzyczne tablice z nazwami miejscowości na Opolszczyźnie: przejaw demokracji czy źródło nowych konfliktów?, „Przegląd Zachodni”, nr 1 (2012), s. 127-142.

Choroś M., O dqż̇eniu do wprowadzenia dwujęzycznych nazw miejscowości na Śląsku Opolskim, „Śląsk Opolski", nr 2 (2001), s. 90-95.

Choroś M., Wprowadzanie podwójnych nazw miejscowości w województwie opolskim, „Rocznik Ziem Zachodnich", t. 1 (2017), s. 360-383.

Choroś M., Jarczak Ł., Wprowadzanie dwujęzycznych nazw miejscowości na Śląsku Opolskim po 1989 roku, „Studia Śląskie”, t. 69 (2010), s. 217-237.

Dżon B., Kogo bolq oczy od niemieckich nazw, „Przegląd”, z 25 V 2008 r.

Godlewska E., Polska ustawa o mniejszościach versus rozwiqzania austriackie - analiza porównawcza, [w:] Między lękiem a nadziejq. Dziesięć lat funkcjonowania ustawy o mniejszościach narodowych i etnicznych oraz o języku regionalnym (2005-2015), red. A. Adamczyk, A. Sakson, C. Trosiak, Poznań 2015, s. 119-130.

Godlewska E., Prawa językowe mniejszości narodowych w Republice Austrii na przykładzie mniejszości słoweńskiej i chorwackiej, „Annales. Universitatis Mariae Curie-Skłodowska” (sectio K), t. 13 (2006), s. 61-71.

Janusz G., Podmiotowa ochrona w ustawie z dnia 6 stycznia 2005 roku o mniejszościach narodowych i etnicznych oraz o języku regionalnym, [w:] Między lękiem a nadziejq. Dziesięć lat funkcjonowania ustawy o mniejszościach narodowych i etnicznych oraz o języku regionalnym (2005-2015), red. A. Adamczyk, A. Sakson, C. Trosiak, Poznań 2015, s. 15-24.

Kersten K., Przemiany struktury narodowościowej Polski po II wojnie światowej. Geneza i wyniki, „Kwartalnik Historyczny”, R. 76 (1969), nr 2, s. 337-366.

Kurasz I., Mniejszość niemiecka na Dolnym Ślq̨sku. Studium socjologiczne, Kraków 2015.

Kurcz Z., Mniejszość niemiecka w Polsce, Wrocław 1995.

Lis M., Górny Ślq̨sk. Zarys dziejów do I wojny światowej, Opole 1993.

Lis M., Górny Ślq̨sk. Zarys dziejów do połowy XX wieku, Opole 2001.

Lis M., Ludność rodzima na Ślq̨sku Opolskim po II wojnie światowej (1945-1993), Opole 1993.

Lis M., Mniejszość niemiecka na Ślq̨sku Opolskim 1989-2014. Z bagażem przeszłości w realiach współczesności, Opole 2015.

Lis M., Polska ludność rodzima na Ślq̨sku po II wojnie światowej (polityczno-społeczne uwarunkowania integracji): próba syntezy, Opole 1991.

Lis M., Ślqsk Opolski w warunkach transformacji ustrojowej państwa od 1989 roku, Opole 2013. 
Łodziński S., „Niebanalna” dwujęzyczność. Polska tożsamość narodowa a granice integracji mniejszości narodowych, [w:] Naród - tożsamość - kultura. Między koniecznościq a wyborem, red. J.W. Burszta, K. Jaskułowski, J. Nowak, Warszawa 2005, s. 177-197.

Łodziński S., Polityka etniczna - od standardu międzynarodowego do prawa krajowego i poziomu lokalnego (gminy). Przykład instytucjonalizacji praw językowych osób należqcych do mniejszości narodowych w Polsce, [w:] Polityka etniczna. Teorie - koncepcje - wyzwania, cz. III: Polityka etniczna państw i regionów, red. T. Browarek, H. Chałupczak, E. Pogorzała, R. Zenderowski, Lublin 2015, s. 379-401.

Łodziński S., Przed ustawq o mniejszościach. Charakter instytucjonalizacji praw osób należqcych do mniejszości narodowych po 1989 roku a ustawa o mniejszościach z 2005 roku, [w:] Między lękiem a nadzieja. Dziesięć lat funkcjonowania ustawy o mniejszościach narodowych i etnicznych oraz o języku regionalnym (2005-2015), red. A. Adamczyk, A. Sakson, C. Trosiak, Poznań 2015, s. 25-37.

Łodziński S., Refleksyjne dziedzictwo? Dodatkowe nazwy niemieckie jako symbol tradycji terytorialnej ojczyzny lokalnej (przykład województwa opolskiego), [w:] Dziedzictwo kulturowe Ślq̨ska. Miejsca. Architektura. Ludzie. Zwyczaje. Tradycje: XVIII Seminarium Ślq̨skie, red. G. Schiller, Kamień Śląski 2013, s. 15-20.

Mazur Z., O adaptacji niemieckiego dziedzictwa kulturowego na Ziemiach Zachodnich i Północnych, Poznań 2001.

Mazur Z., Rozmowy o niemieckim dziedzictwie kulturowym. Raport ze spotkań środowiskowych na Ziemiach Zachodnich i Północnych (1995-1996), Poznań 1997 (mps niepublikowany).

Między lękiem a nadziejq. Dziesięć lat funkcjonowania ustawy o mniejszościach narodowych i etnicznych oraz o języku regionalnym (2005-2015), red. A. Adamczyk, A. Sakson, C. Trosiak, Poznań 2015.

Miś E., Ohne Gewalt. Eine Glosse über die zweisprachigen Ortsnamen in der Gemeinde Bierawa, „Schlesisches Wochenblatt", nr 28, z 10-16 VII 1998 r.

Mniejszości narodowe w Polsce. Praktyka po 1989 roku, red. B. Berdychowska, Warszawa 1998.

Nijakowski L.M., Domeny symboliczne. Konflikty narodowe i etniczne w wymiarze symbolicznym, Warszawa 2006.

Nitschke B., Przeobrażenia i specyfika działalności organizacji mniejszości niemieckiej, [w:] Między lękiem a nadziejq. Dziesięć lat funkcjonowania ustawy o mniejszościach narodowych i etnicznych oraz o języku regionalnym (2005-2015), red. A. Adamczyk, A. Sakson, C. Trosiak, Poznań 2015, s. 157-158.

Pawlak A., Wielkie Opole nie po niemiecku. Zniknq dwujęzyczne tablice z nazwami miejscowości, „Gazeta Wyborcza", z 5 VIII 2016 r.

Polityka państwa polskiego wobec mniejszości narodowych i etnicznych, red. L.M. Nijakowski, Warszawa 2005.

Popieliński P., Wpływ ustawy o mniejszościach narodowych i etnicznych oraz o języku regionalnym na funkcjonowanie środowiska mniejszości niemieckiej w Polsce, [w:] Między lękiem a nadziejq. Dziesięć lat funkcjonowania ustawy o mniejszościach narodowych i etnicznych oraz o języku regionalnym (2005-2015), red. A. Adamczyk, A. Sakson, C. Trosiak, Poznań 2015, s. 217-230.

Sadowski A., Ustawa o mniejszościach a procesy narodowotwórcze na pograniczach, [w:] Między lękiem a nadziejq. Dziesięć lat funkcjonowania ustawy o mniejszościach narodowych i etnicznych oraz o języku regionalnym (2005-2015), red. A. Adamczyk, A. Sakson, C. Trosiak, Poznań 2015, s. 39-51.

Sakson A., Rola mniejszości niemieckiej w stosunkach polsko-niemieckich na przykładzie Warmii i Mazur, „Zeszyty Instytutu Zachodniego”, nr 11 (1998), s. 1-21.

Siegień-Matyjewicz A.J., Prawo do dwujęzyczności - zgoda czy konflikt? Raport z badań dotyczqcych dwujęzyczności osób pochodzenia białoruskiego zamieszkujących tereny Wschodniego Podlasia, „Pogranicze. Studia Społeczne", t. XVII (2011), s. 229-244. 
Tokarz K., Mniejszość niemiecka w Polsce w prasie RFN lat 1989-1997, [w:] Węzłowe problemy Niemiec XX-XXI wieku, red. K. Fiedor, M.S. Wolański, Wrocław 2002, s. 153-168.

Tożsamość narodowa i postrzeganie praw mniejszości narodowych i etnicznych, oprac. M. Omyła-Rudzka, „Komunikat z Badań”, nr 106 (2015).

Tożsamość narodowa Polaków oraz postrzeganie mniejszości narodowych i etnicznych w Polsce. Komunikat z badań, oprac. J. Lewandowska, Warszawa 2005.

Trzcielińska-Polus A., Mniejszość niemiecka na Śląsku Opolskim - atut czy wyzwanie dla regionu?, [w:] Między lękiem a nadziejq. Dziesięć lat funkcjonowania ustawy o mniejszościach narodowych $i$ etnicznych oraz o języku regionalnym (2005-2015), red. A. Adamczyk, A. Sakson, C. Trosiak, Poznań 2015, s. 145-155.

Wagińska-Marzec M., Kwestia podwójnego nazewnictwa miejscowości na Opolszczyźnie w stosunkach polsko-niemieckich, „Opinie i Ekspertyzy”, nr 5 (2004), s. 1-44.

Wagińska-Marzec M., Postawy mieszkańców Opolszczyzny wobec podwójnych nazw miejscowości, „Zeszyty Instytutu Zachodniego”, nr 31 (2003), s. 1-68.

Wagińska-Marzec M., Problem nazewnictwa na Ziemiach Zachodnich i Północnych w świetle ustawy o mniejszościach narodowych i etnicznych, [w:] Ziemie Zachodnie i Północne 1945-2005. 60 lat w granicach państwa polskiego, red. A. Sakson, Poznań 2006, s. 301-342.

Wagińska-Marzec M., Spory o nazwy miejscowości na Opolszczyźnie jako syndrom walki o tradycję, „Zeszyty Instytutu Zachodniego”, nr 27 (2002), s. 1-46.

Węsierski M., Na Kaszubach przybywa dwujęzycznych nazw miejscowości. Gminy za nowe tablice nie płacq, „Dziennik Bałtycki”, z 7 III 2013 r.

\section{Netografia (wybór)}

Biły Ł., Dwujęzyczne tablice z nazwami miejscowości, 24 IX 2012 r., http://vdg.pl/pl/article/39dwujezyczne-tablice-z-nazwami-miejscowosci.

Guzik P., Łodziński M., Większe Opole. Rzq̨d zatwierdzi poszerzenie granic miasta w 2017 roku!, 19 VII 2016 r., http://opole.wyborcza.pl/opole/1,35086,20423849,wieksze-opole-rzad-zatwierdzil-poszerzenie-granic-miasta.html.

Guzik P., Prezydent Duda przeciwny językowi mniejszości w urzędach. Niemcy i Kaszubi: Absurd, 28 X 2015 r., http://wyborcza.pl/1,75398,19099196,prezydent-duda-przeciwny-jezykowi-mniejszosci-w-urzedach-niemcy.html.

Szewczyk M., To jest test tolerancji. Pojawiły się polsko-niemieckie nazwy miejscowości (TV), 24 I 2014 r., http://www.24gliwice.pl/wiadomosci/to-test-tolerancji-dla-gliwic-polsko-niemieckie-nazwy -miejscowosci-tv/. 


\section{Proces wprowadzania dwujęzycznych nazw miejscowości na Opolszczyźnie i ich społeczny odbiór}

Streszczenie: Lata 90. ubiegłego stulecia sprawiły, że na fali przemian ustrojowo-demokratycznych w Polsce na terenach zamieszkanych przez mniejszości narodowe i etniczne zaczęto podejmować działania zmierzające do zamanifestowania własnej tożsamości w przestrzeni publicznej. Jednym z tego przejawów było dążenie do wprowadzenia nazw miejscowości w języku mniejszości na tablicach drogowych. Umożliwiła to oficjalnie dopiero Ustawa o mniejszościach narodowych i etnicznych oraz o języku regionalnym z $2005 \mathrm{r}$. W opracowaniu został przedstawiony przebieg wprowadzania dwujęzycznych nazw na terenie Śląska Opolskiego jako największego skupiska ludności pochodzenia niemieckiego, a także działania administracji z tym związane oraz towarzyszące temu procesowi reakcje społeczne. W tekście podjęta została próba pokazania różnorodności postaw mieszkańców regionu wobec polsko-niemieckich nazw miejscowości (od pełnej akceptacji podwójnego nazewnictwa przez postawy obojętne po całkowite odrzucenie).

\section{Process of the introduction of bilingual place names in Opole region and its societal reception}

Abstract: In the 1990s and on the wave of the structural and democratic changes occurring in Poland, campaigns were conducted in areas with national and ethnic minority communities aimed at manifesting the identities of these groups in the public sphere. One of these displays was the success in introducing place names in minority languages on road signs. This was made officially possible by the 2005 law concerning national and ethnic minorities and regional languages. The article presents the course of the introduction of bilingual names in Opole Silesia region which represents the largest concentration of people of German origin. The paper also discusses the administrative work connected with this policy and the societal reactions accompanying this process. The text attempts to demonstrate the variety of attitudes held by residents of the region towards Polish-German place names (from full acceptance of dual naming via indifference to complete rejection).

Słowa klucze: Opolszczyzna, Śląsk Opolski, Ustawa o mniejszościach narodowych i etnicznych, dwujęzyczne nazwy miejscowości

Keywords: Opole region, Opole Silesia, Act concerning national and ethnic minorities, bilingual place names 